\title{
VARIEDADES DE CAFEEIROS
}

\section{CARLOS TEIXEIRA MENDES}

Professor Catedrático de Agricultura Especial da Escola Superior de Agricultura "Luiz de Queiroz", da Universidade de São Paulo

Recebiđo para publicação em 15-7-1948. 
Na luta em que se empenham técnicos e fazendeiros, com - fim de restaurar o cafezal paulista, redimindo uma parte das erros do passado, tóda observaçáa baseada em fatos e, especialmente, na experimentação, pode constituir contribuição útill, mesmo modesta como a que agora expomos. (1)

No estudo das variedades de cafeeiras que povoam o Estado de são Paulo, além de mil outros detalhes correlacionadas com sua cultura e sua genética (produtividade, rusticidade etc.) podemos levar em consideração outras dois pontas de vista : o da "bebida" e o do "tilpo". Em relação à primeira, não será preciso perdier muito tempo para demonstrar que as variedades predominantes em nossas culturas năo constituem a causa das bebidas finas ou das menos boas. Ao meio em que vivem é que se deve imputar, mais que a tudo, a razăo do fato. As duas variedades que englobam de modo quase absoluto, nossas culturas, são a "Nacional" e a "Burbon", as mesmas que, de Campinas para o Norte do Estado produzem afamados cafés e que, na Sorocabana te no vale do Paraiba só contrlbuem com produtos indiscutivelmente inferiores aos daquela zona.

Se fósse necessário, contudo, de experiências comparativas dieduzir quaisquer conclusões, bastaria que citássemos alguns exemplos presentes em nossas trabalhos:

10.) - Em um ano, tanto o "Nacional", como o "Burbon", o "AMARELO de Botucatú" e o "Sumatra", todas em perfeita igualdade de condiçães, só prođuziram bebidas excelentes; no ano seguinte, ao contrário, as mesmas quatro variedades, em outras experiências, só nos proporcionaram bebida "dura", em consequencia do decorrer do tempo e de seu reflexo sobbre a secagem do café;

20.) - O afamado "Burbon", que em determinada experiencia só produziu o "estritamente mole", em outra, tanto produziu essa bebida, como o "mole boa" e "dura", em estreita correlação com a quantidade de frutos verdes que continha, produto do momento, muitas vezes forçado, de colheita. Em outra experiência só nos proporcionou bebidas péssimas;

(1) - Na parte de Campo dêste trabralho, fomos muito pruxilliadio pelo agrônomo Eduardo Mezzacappa, administrador da Fazenda Modelo. 
30.) - Para năo nos alongarmos demasiadamenté, deixamas de expor váiras casos, que um dia descreveremos, - sóbre os efeitos do sombreamento e das adubaçóes, nos quais encontrámos as mais variadas bebidas em qualquer das quatro variedades atrás mencionadas.

Concluimos dizendo que as variedades mais cultivadas no Estado de Săo Paulo náo podem ser responsabilizadas pelas qualidades da bebida do café, pasto que em relaça ao "Bourbon" haja um certa tendencia entre os nossos fazendelros, para atribuir-lhes melhores qualidades de paladar, fama talvez merecida, provàvelmente produto de ter predominado nas culturas da zona de nossas melhores cafés.

Histes exemplos e esta tese náo excluem a póssibilidade de se isolarem linhagens piores ou melhores dessas mesmas ou de outras variedades.

Deixando de lado a questăo da "beblda", restringir-nosemos, neste artigo, de preferência, ao papel que passam desempenhar essas variedades sobre o "tipo" ou tamanho da semente do café, da "fava", como se diz na giria comercial desse produto.

Ninguem porá em dúvida que è o "Maragogipe" o produtor das maiores e mais belas "favas"; menores produzem o "Amarelo de Botucatu" e o "Nacional" e bem menores ainda săo as do "Burbon".

Outras experiências comparativas năo conhecemos que possamos citar e, por esse motivo, somos obrigado a nas cingir exclusivamente aos nossos proprias trabalhas, com o fim de verificarmos se há, de fato, ponderávels diferenças entre os produtos das variedades mais disseminadas em nosso Estado.

Com êsse fím, tomámos quatro talhóes de cáfeeiros que passuiamas na Fazenda Modelo, um de cada uma das variedades adiante menciondas, de um cafezal novo, de sete anos de idade no inicio desta experiência, em plena produçăo. Tratava-se de uma cultura instalada em terra roxa "iencaroçada" de diabásio, velhissima de culturas anteriores, mas de tal modo tratada, que o cafezal apresentava excelente aspecto, como se vegetosse em terra nova.

Para se tornarem apreensiveis tantos nủmeros como os que nas fol necessário estudar, vamos resumí-los, o mais que nos for passivel, exprimindo-os, primeiramente em relação a uma quantidadie constante, mil quilos de café em côco. Como é 
hábito, porém, de nassos fazendeiras tudo representar em alqueires (que nem sempre são de 50 litros), desde a colheita até o beneficiamento, para nesse momento, passar de uma medida de volume para uma táo diversa de peso - a arroba de 15 quilos - devemos dizer que não é possível, senăo de modo muito grosseiro, estabelecer uma relação entre o volume do café em "cóco" e seu pêso. Essa verdade demonstramos com o Quadro I, no qual podiemos constatar que mil litros de café em cóco, pronto para ser recolhido à tulha, tanto podem pesar 370 quilos, como 420, se do "Burbon", ou de 380 a 429, se do "Nacional" e assim para os demais. Este fato está correlacionado com vários fatores, dentre as quais sobressal o estado de maturação com o qual se realizar a colheita. De um modo geral, porém, podemos dizer que cem litros de um bom "café em cóco" devem pesar, aproximadamente, quarenta quilos, que beneficiados, podem nos dar vinte e dois quilos de café total e, em funçáo de suas qualidades, até dezoito quilos de "cafés bons", vendáveis, ou seja, $85 \%$.

Se é difícil estabelecer uma relaçăo entre pêso e volume do café em cóco, plor seria se o tentássemos fazer entre o "cereja" e o "cóco", quer encarando volumes ou pesas.

$O$ peso e o volume do café ım cereja nada representam; hão de ser, sempre, medidas variabilissimas, em funçăo do estado de maturaçáo, consequentemente das quantidades de água que encerram os frutos, ou seja, das porcentagens relativas de frutos verdes, sêcos ou maduros em dado momento da colheita.

Uma vez secos os frutos e guardados sob forma de "café em cóco", podemas dizer que só tendem a aumentar de peso, tão raras e insignificantes são as excessర6es neveladas em nosso Quadro I. Esse aumento provàvelmente náo afetará as sementes; é decorrente da higroscopicidade da casca sêca do fruto.

Feitas estas observaçбes, prossigamas no relato de nassas experiencias, as quais tem por fim estudar o tamanho das sementes produzidas por quatro variedades, em perfeita igualdade de condiçбes.

Tomemos em primeiro lugar o nosso Quadro II, do qual todas as números foram calculados para uma mesma quantidade de "café em cóco" (mil quilos), com o fim de se tornarem mais fàcilmente apreensíveis.

Náo estamas, neste momento, estudando a variação de produção das diversas variedades, o que reservamos para o Quadro VI; estamos apenas mostrando como são variáveis, de ano para ano, as quantidades de café de cada "tipo", se a esse têrmo, muito difundido no comércio de café, só emprestar- 


\begin{tabular}{|c|c|c|c|c|c|c|c|c|c|c|c|c|c|c|c|c|c|c|c|c|}
\hline \multirow[b]{2}{*}{ Variededes } & \multicolumn{5}{|c|}{$\begin{array}{c}\text { Colheita de } 1932 \text { com "broca" } \\
\text { regular (1) }\end{array}$} & \multicolumn{5}{|c|}{$\begin{array}{c}\text { Colheita de } 1933 \text { com } \\
\text { bastante "broca" }\end{array}$} & \multicolumn{5}{|c|}{$\begin{array}{l}\text { Colheita de } 1934 \text { com muita } \\
\text { "broca" }\end{array}$} & \multicolumn{5}{|c|}{ Colheita de 1935 com pouca } \\
\hline & 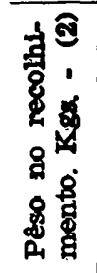 & 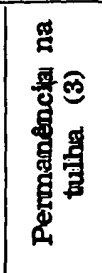 & 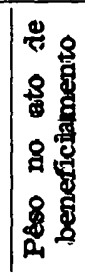 & 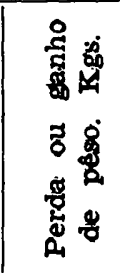 & 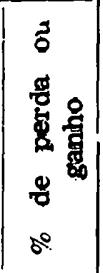 & 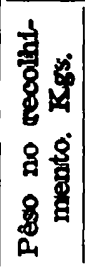 & 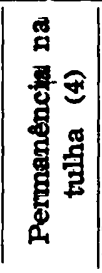 & 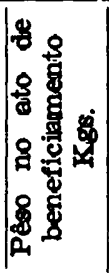 & 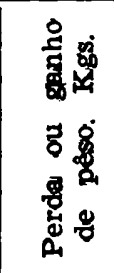 & 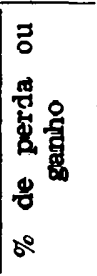 & 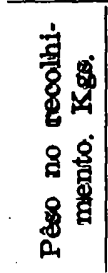 & 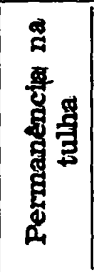 & 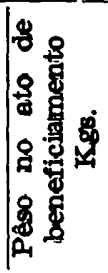 & 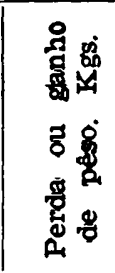 & 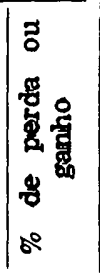 & 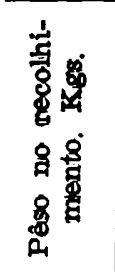 & 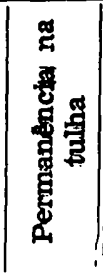 & 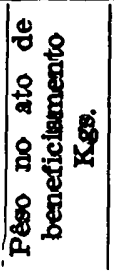 & 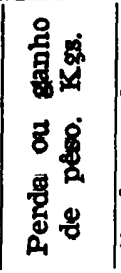 & 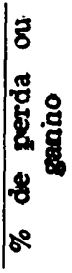 \\
\hline \multirow[t]{2}{*}{$\begin{array}{l}\text { Sumatra } \\
\text { Burbon } \\
\text { Nacionil } \\
\text { Amarelo do } \\
\text { Botucath }\end{array}$} & $\begin{array}{l}400 \\
385 \\
395\end{array}$ & $\begin{array}{c}1-a \\
" 0 \\
" \\
"\end{array}$ & $\begin{array}{l}407 \\
390 \\
385 \\
405\end{array}$ & $\begin{array}{r}+\quad 7 \\
+\quad 5 \\
+\quad 10 \\
0\end{array}$ & $\begin{array}{r}1,75 \\
1,32 \\
2,53 \\
0\end{array}$ & $\begin{array}{l}\overline{370} \\
380\end{array}$ & $\begin{array}{c}-\overline{254 d} \\
240 d \\
262 d\end{array}$ & $\begin{array}{l}-\overline{373}, 5 \\
380,5 \\
399,0\end{array}$ & $\begin{array}{r}-\overline{3,5} \\
+\quad 0,5 \\
+10,0\end{array}$ & $\begin{array}{l}\overline{0,90} \\
0,13 \\
2,60\end{array}$ & $\begin{array}{l}385,0 \\
389,5 \\
400,0 \\
\\
407,0 \\
\end{array}$ & $\begin{array}{l}42 \mathrm{~d} \\
39 \mathrm{~d} \\
36 \mathrm{~d} \\
41 \mathrm{~d}\end{array}$ & $\begin{array}{l}385,0 \\
389,0 \\
400,0 \\
407,0\end{array}$ & $\begin{array}{l}0,0 \\
0,0 \\
0,0 \\
\\
0,0 \\
\end{array}$ & $\mid \begin{array}{l}0,0 \\
0,0 \\
0,0 \\
0,0\end{array}$ & $\begin{array}{l}420,0 \\
420,0 \\
422,5 \\
421,5\end{array}$ & $\begin{array}{l}189 d \\
190 d \\
190 d \\
200 d\end{array}$ & $\begin{array}{l}428,0 \\
429,5 \\
431,0 \\
434,5\end{array}$ & $\begin{array}{r}+8,0 \\
+\quad 9,5 \\
+8,5 \\
+13,0\end{array}$ & $\begin{array}{l}1,9 \\
2,2 \\
2,0 \\
3,0 \\
\end{array}$ \\
\hline & \multicolumn{5}{|c|}{ Colheita de 1936 com pouca } & \multicolumn{5}{|c|}{$\begin{array}{c}\text { Colheita de } 1937 \text { com muito } \\
\text { pouca "broca" }\end{array}$} & \multicolumn{5}{|c|}{$\begin{array}{c}\text { Colheita de } 1938 \text { com muito } \\
\text { pouca "broca" }\end{array}$} & \multicolumn{5}{|c|}{$\begin{array}{c}\text { Colheita de } 1940 \text { com pou- } \\
\text { quissima "broca" (5) }\end{array}$} \\
\hline $\begin{array}{l}\text { Sumatre } \\
\text { Burbon } \\
\text { Nacionial } \\
\text { Amanelo do } \\
\text { Batucati }\end{array}$ & $\begin{array}{l}405 \\
410 \\
406\end{array}$ & $\begin{array}{c}255 \mathrm{~d} \\
"\end{array}$ & $\left|\begin{array}{l}410 \\
420 \\
405 \\
425\end{array}\right|$ & $\begin{array}{r}+5,0 \\
+10,0 \\
+\quad 1,0 \\
+10,0\end{array}$ & $\begin{array}{l}1,23 \\
2,43 \\
0,24 \\
2,41\end{array}$ & $\begin{array}{l}410 \\
400 \\
400 \\
410\end{array}$ & $\begin{array}{c}9 \mathrm{~m} \\
"\end{array}$ & $\mid \begin{array}{l}420,0 \\
405,0 \\
409,0 \\
412,5\end{array}$ & $\begin{array}{r}+10,0 \\
+5,0 \\
+\quad 9,0 \\
+2,5\end{array}$ & $\begin{array}{l}2,50 \\
1,25 \\
2,25 \\
0,60\end{array}$ & $\begin{array}{l}370,0 \\
355,0 \\
378,5 \\
360,5\end{array}$ & $\left|\begin{array}{c}19 \mathrm{~m} \\
" \\
"\end{array}\right|$ & $\left|\begin{array}{l}370,0 \\
358,0 \\
387,0 \\
370,5\end{array}\right|$ & $\begin{array}{r}0,0 \\
+\quad 3,0 \\
+8,5 \\
+10,0\end{array}$ & $\begin{array}{l}0,0 \\
0,8 \\
2,2 \\
2,8\end{array}$ & $\begin{array}{l}380,0 \\
385,0 \\
400,5 \\
395,0\end{array}$ & $\begin{array}{l}160 d \\
170 d \\
195 d \\
170 d\end{array}$ & $\begin{array}{l}400 \\
404 \\
429 \\
\\
408\end{array}$ & $\begin{array}{l}20,0 \\
19,0 \\
28,5 \\
\\
13,0\end{array}$ & $\begin{array}{l}5,2 \\
4,9 \\
7,1\end{array}$ \\
\hline
\end{tabular}

(1) - Com essa expressão, e equivalentes nos anos seguintes, pretendemas representar o major ou menor gráo de infestaçøo das frutas pela "broca do cafe" (Hipothenemus Hampe1).

(2) - Subentende-se, em todas os casos, mil litros de café em "coco".

(3) - Abreviaturas : a - ano, $\mathbf{m}$ - meses e d - dias.
(4) - O café em "coco" foi sempre guardado em sacas na tulha, no melo do café a granel.

(5) - Na fizemos determinaçסes em 1939 em consequencia de terrivel "chuva de pedras" ter inutilisado varias de nossas experiencias. 
mas a significação do tamanho da semente, o que é designado, nesse mesmo comércio, pela expressão "peneira".

o equivalente désse quadro, sob forma mais simples, é o de número III, no qual expomos, năo mais as quantidades reais mas sim as porcentagens com que entram os diversas tipos no conjunto de cada colheita. Dêle se deduz, como é fácil de ver, a grande variabilidade na composição da produção de cada an.o

As quatro variedades mostram, para as duas primeiras peneiras (sempre consideradas como uma só) uma tendência acentuada de decrécimo, com o decorrer dos anos, ainda que, com variações bruscas interrompendo essa manifestação, coincidientemente para tôdas as variedades nos anas de 1935, 1937 e 1940 .(2)

Procurando as causas dêste último fenomeno, so encontrámas como explicaçăo, a coincidência de pequenas produçóes nesses anos (com uma única exceção para o "Amarelo de Botucatú", em 1937), consequência provável da probreza de chuvas nos anos precedentes, como se demonstra no Quadro VI.

$O$ aumento das porcentagens dessas duas peneiras năo determina, como poderia parecer necessário, diminuiçăo correlativa nas que the ficam logo abaixo, como se deduz do Quadro IV, se considerarmas o conjunto todo diessas cinco peneiras e dos "mocas", o que vai colocar a questão sob ddis aspectos diferentes:

1) - As proporções dêsse conjunto, que naquele quadro chamamos de "cafés bons", em relação ao "café em côco", melhoraram em seis casos e pioraram em outros seis;

2) - Essas proporçóes em relação ao total de café beneficiado, ao contrário, mostram melhoria iem nove casos, contra um de piora e dos duvidosos.

Se, entretanto, sòmente considerarmos as três peneiras que lhes ficam logo abaixo, verificamos, como é forçaso, que o aumento das de N.os 18 e 19 , conduz a diminuição nas de N.os 15,16 e 17.

O gráfico II, grupando de outro modo esses dols conjuntos, nos mastra sua correlação durante o período de 7 anos em que foram mais regulares nossas observaçōes.

(2) - Pana análise mais rigonosa devemos só eproveitar, clora êste traballho, os dados até 1928, porque só até então tivemos condições que permitissem comparações em iguxidade de condiçōes, como veremos adiante. 


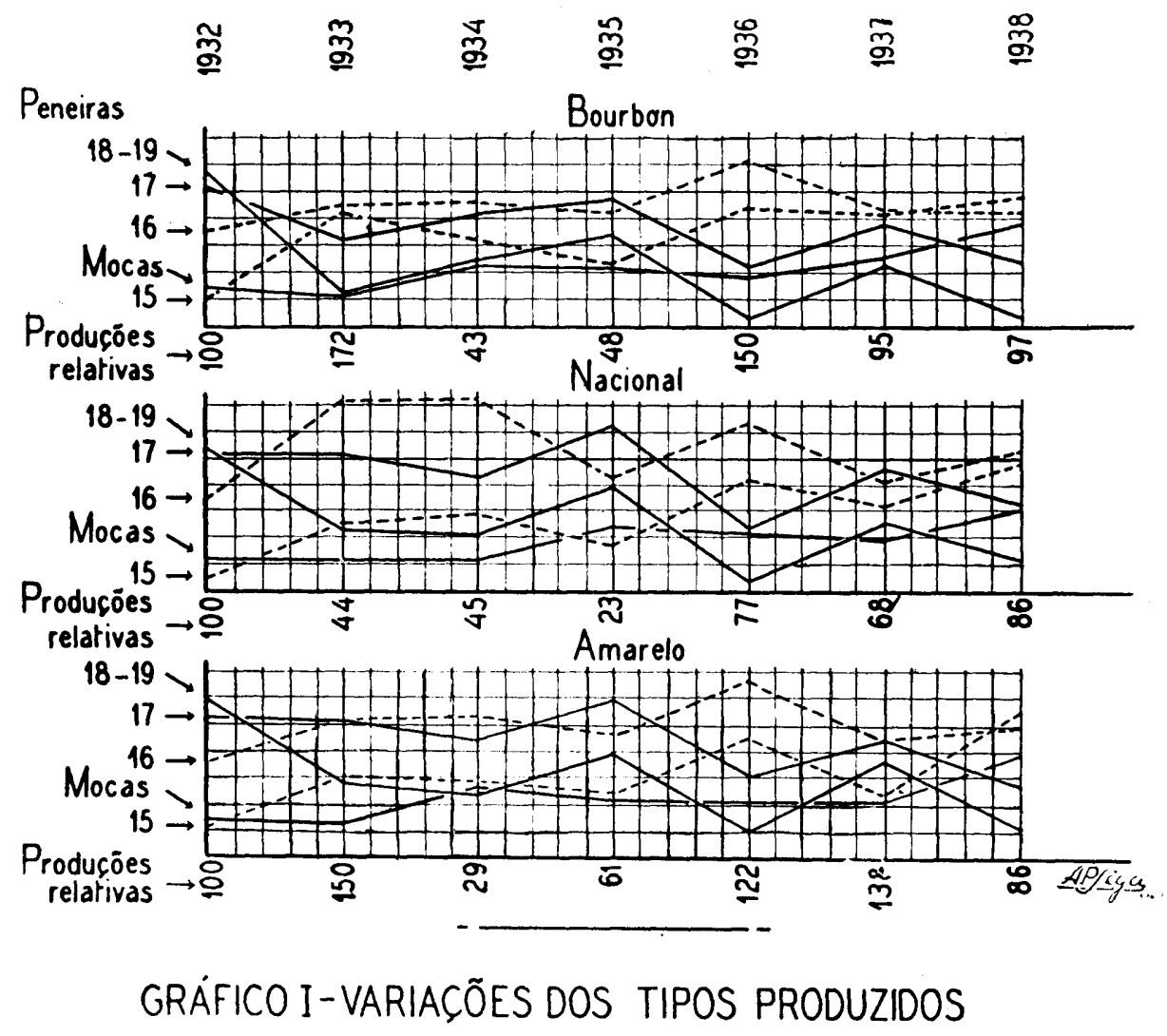




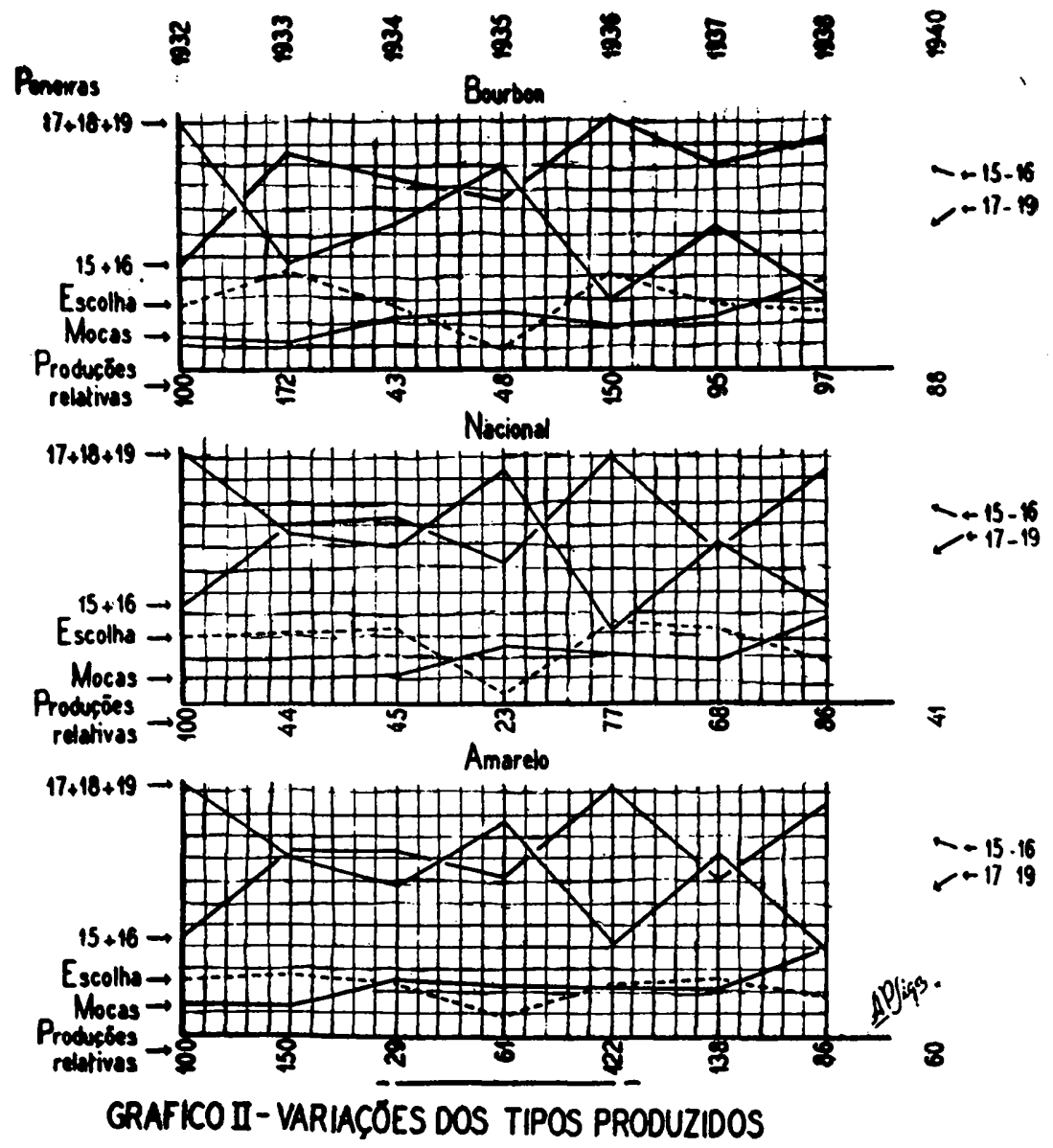


Couclusão - A melhoria de proporçães das duas primeiras peneiras equivale à melhoria do conjunto que chamamos de "cafés bons", senão em relação ao "café em cóco", o que fica em dúvida, pelo menos sm relação ao total de café beneficiado. Essa melhoria parece estar correlacionada com as pequenas produçőes.

Corroborando essa asserção, verificamos que a referida melhoria coincide, em quase todos os casos, com diminuição do "café escolha", quer em relaçăo ao "café em côco", quer, e mais pronuncidamente, em confronto com o "café beneficiado", como é natural.

Continuando a observar êsses resultados pelo prisma da proporcionalidade, ie chamando de "cafés bons" o conjunto das cinco primeiras peneiras e as três de "mocas", evidenciase que não há diminuiçăo de sua produçăo com o decorrer dos anos, pôsto que variaçóes sensiveis sejam observadas.

Quanto à produtividade real nada podemos deduzir de nossas experiencias, por vários motivos, dentre as quais o termos iniciado um cafezal em terra gastissima, mantida a pêso de artifícios, além de termos que abandoná-la em parte, em consequência de grande invasão de tiririca.

Calculando, porém, a produção por "mil pés de café", chegaríamos à conclusão de que o "Sumatra" foi, durante dez anos, o mais produtívo, vencendo os demais por larga margem. Como, porém, a experiência náo visava êsse fím, fica o asserto com o valor apenas de observação.

Se para o chamado conjunto de "cafés bons" năo verificamos tendência manifesta e contínua de diminuição com o envelhecer das plantas, não se pode negar que ela se nevela no aumento das porcentagens de "mocas", de modo significativo e paralelo em seus resultados finais; quanto ao café "escolha", contudo, năo se observa igual tendência.

Quanto a produção, reconhecidamente oscilante em um cafezal, de ano para ano, ainda que as condiçбes de nossas experiênclas năo fôssem perfeitas para seu estudo, parece que menos variáveis se mostraram o "Burbon" e o "Nacional" e mais inconstantes o "Amarelo" e, especialmente, o "Sumatra".

Cabe aqui, contudo, uma observação: as técnicos especialistas do Instituto Agronómico de Campinas năo encontraram em suas pesquisas, elementas biométricos bastantes para fazer do "Sumatra" uma variedade distinta do "Nacional"; ao contrário, asseveram ser erróneo o conceito de variedade, e 
QUADRO II

Mil quilos de caté em côco produziram :

\begin{tabular}{|c|c|c|c|c|c|c|c|c|c|c|c|c|c|c|c|c|c|c|c|c|c|c|c|c|c|c|c|c|c|c|c|c|c|c|c|c|c|c|c|c|}
\hline \multirow[b]{2}{*}{$\begin{array}{l}\text { "Peneiras" ou tipos } \\
\text { produzidas (1) }\end{array}$} & \multicolumn{10}{|c|}{ Sumatra } & \multicolumn{10}{|c|}{ Burbon } & \multicolumn{10}{|c|}{ Nacional } & \multicolumn{10}{|c|}{ Amarelo de Botucatú } \\
\hline & 蔃 & 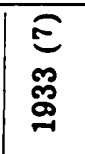 & 苗 & 怘 & 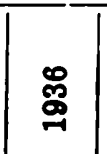 & 畣 & 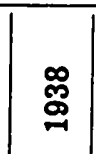 & 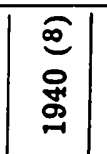 & 今 & 节 & 嘫 & 粱 & 楞 & 崫 & 怘 & 商 & 怘 & 导 & 蛋 & 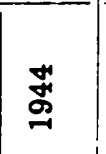 & 嘿 & 粱 & 䍛 & 怘 & $\mid$ & 商 & 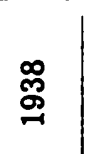 & 兽 & ఫ్ & 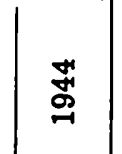 & 蔃 & 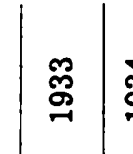 & 芯 & 怘 & 怘 & 粱 & 离 & 导 & 哥 & 莒 \\
\hline 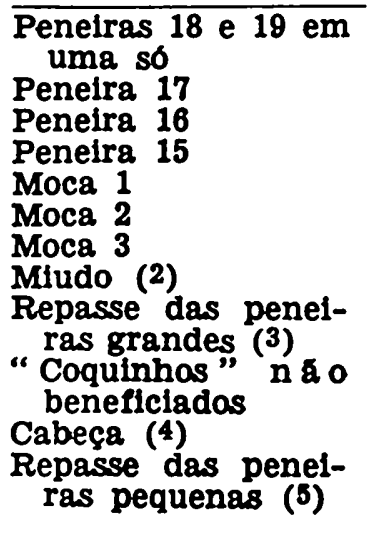 & $\begin{array}{r}137,8 \\
167,3 \\
131,4 \\
41,7 \\
19,6 \\
18,4 \\
2,4 \\
14,7 \\
12,7 \\
8,0 \\
2,5 \\
24,0 \\
\end{array}$ & $\begin{array}{l}= \\
\equiv \\
\bar{z} \\
= \\
= \\
-\end{array}$ & $\mid \begin{array}{r}53,2 \\
106,7 \\
130,1 \\
75,8 \\
14,2 \\
28,5 \\
4,9 \\
9,1 \\
14,8 \\
|4,| \\
3,1 \\
0,0 \\
86,0 \mid \\
1\end{array}$ & 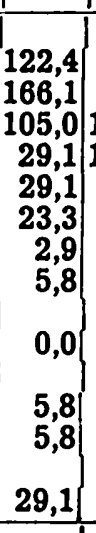 & 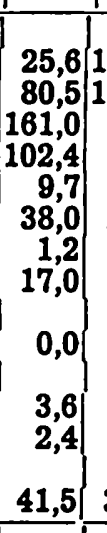 & $\mid \begin{aligned} 100,0 \\
105,0 \\
96,8 \\
64,1 \\
64, \\
134, \\
24,4 \\
5,0 \\
9,2 \\
5,0 \\
5,0 \\
6,1 \\
6,1 \\
30,0 \\
\end{aligned}$ & $\begin{array}{r}43,5 \\
88,0 \\
129,0 \\
117,1 \\
7,5 \\
25,5 \\
45,0 \\
7,5 \\
6,0 \\
6,0 \\
7,5 \\
3,0 \\
76,5 \\
76\end{array}$ & $\mid \begin{array}{r}58,7 \\
146,2 \\
107,5 \\
65,01 \\
13,7 \\
25,0 \\
8,0 \\
18,2 \\
0,8 \\
0,8 \\
0,6 \\
0,8 \\
40,0 \\
\end{array}$ & $\begin{array}{r}85,3 \\
126,8 \\
114,1 \\
6,1 \\
33, \\
15,3 \\
59,4 \\
59,7 \\
5,7 \\
0,8 \\
0,0 \\
0,8\end{array}$ & $\begin{array}{r}3,2 \\
98,9 \\
129,6 \\
126,2 \\
6,4 \\
34,7 \\
15,5 \\
25,9 \\
29,3 \\
0,2 \\
0,0 \\
20,3 \\
\end{array}$ & \begin{tabular}{|r|}
173,0 \\
136,5 \\
135,4 \\
31,0 \\
22,4 \\
18,6 \\
11,6 \\
11,2 \\
3,3 \\
8,0 \\
15,4 \\
51,9 \\
\end{tabular} & $\begin{array}{r}32,1 \\
91,0 \\
119,6 \\
8,1 \\
86,0 \\
26,1 \\
26, \\
26, \\
6,7 \\
6,7 \\
0,0 \\
78,9 \\
7\end{array}$ & \begin{tabular}{r|r|}
50,7 & \\
104,3 & 1 \\
130,0 & 1 \\
81,0 & \\
13,8 & \\
33,6 & \\
70,7 & \\
10,2 & \\
9,4 & \\
4,0 & \\
0,0 & \\
47,4 & \\
\end{tabular} & \begin{tabular}{|r|}
83,7 \\
132,6 \\
117,4 \\
66,2 \\
20,9 \\
30,2 \\
11,6 \\
4,6 \\
0,0 \\
0,0 \\
7,0 \\
4,6 \\
5,8 \\
5,8
\end{tabular} & $\begin{array}{rl}17,2 & \\
51,6 & 11 \\
130,9 & 1 \\
108,4 & 1 \\
71,9 & \\
11,7 & \\
15,8 & \\
15,5 & \\
10,5 & \\
4,0 & \\
2,6 & \\
52,9 & \end{array}$ & $\begin{array}{rl}67,1 & \\
10,8,8 & \\
132,6,5 & 1 \\
13,7 & 1 \\
37,0 & \\
9,5 & \\
19,7 & \\
8,2 & \\
8,2 & \\
6,8 & \\
40,5 & \\
\end{array}$ & \begin{tabular}{r|r}
19,7 & 1 \\
$61,1,1$ & 1 \\
152,0 & 1 \\
6,2 & \\
$34,5,5$ & \\
66,8 & \\
3,1 & \\
7,8 & \\
9,4 & \\
3,1 & \\
47,0 & \\
\end{tabular} & 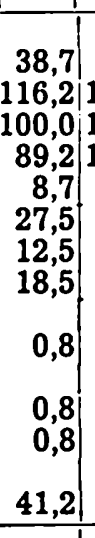 & $\mid \begin{array}{r}7,4 \\
10,9 \\
107,8 \\
10,91 \\
3,9 \\
34,0 \\
14,8 \\
63,6 \\
53,2 \\
3,2 \\
3,0 \\
0,6 \\
1,4 \\
\end{array}$ & $\begin{array}{r}4,7 \\
88,2 \\
115,3 \\
156,4 \\
7,1 \\
36,7 \\
21,4 \\
29,4 \\
33,2 \\
5,3 \\
0,0 \\
0,7 \\
\end{array}$ & $\mid \begin{array}{r}171,4 \\
176,5,1 \\
110,9,1 \\
25,9, \\
20,7 \\
16,8 \\
1,3 \\
9,6 \\
3,8 \\
3,8 \\
8,3 \\
13,5 \\
55,0 \\
\end{array}$ & $\begin{array}{r}67,1 \\
146,0 \\
72,3 \\
72,3 \\
82,4 \\
0,3 \\
0,0 \\
14,4 \\
8,0 \\
4,4 \\
0,0 \\
61,8 \\
6\end{array}$ & 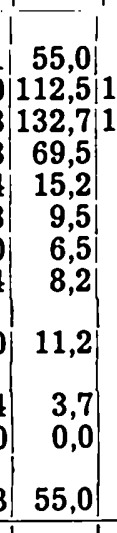 & 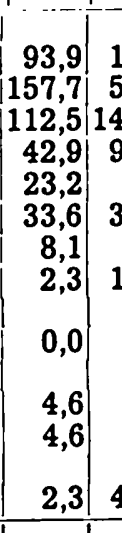 & 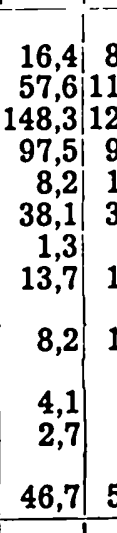 & $\begin{array}{r}82,4 \\
18,9, \\
127,71, \\
91,9,1 \\
12,1 \\
36,5 \\
8,6 \\
14,3 \\
12,1 \\
8,1 \\
5,9 \\
52,7 \\
52,7\end{array}$ & $\begin{array}{r}31,5 \\
88,5,1 \\
147,3,1 \\
133,0 \\
9,0 \\
97,4 \\
38,7 \\
1,3 \\
6,4 \\
5,1 \\
2,1 \\
2,6 \\
37,4\end{array}$ & $\begin{array}{r}38,4 \\
124,4 \\
10,1,2 \\
79,0 \\
8,1 \\
83,7 \\
10,7 \\
20,7 \\
0,9 \\
0,7 \\
0,7 \\
33,7 \\
\end{array}$ & $\begin{array}{r}6,4 \\
140,5 \\
91,4 \\
98,8 \\
5,5 \\
38,1 \\
14,3 \\
36,9 \\
45,7 \\
4,7 \\
0,5 \\
0,0 \\
0,5 \\
\end{array}$ & $\begin{array}{l}8,8 \\
123,4 \\
94,1 \\
94,6 \\
120,4 \\
50,4 \\
14,0 \\
15,1 \\
48,8 \\
40,8 \\
0,5 \\
0,2 \\
0,2 \\
0.2\end{array}$ & 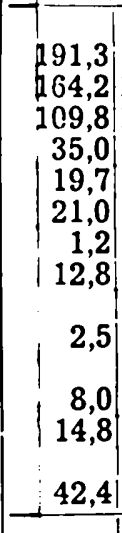 & 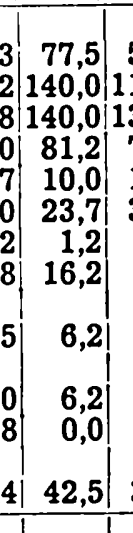 & 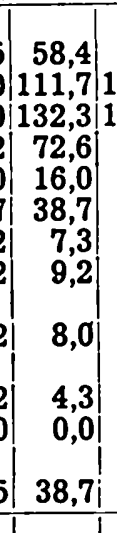 & \begin{tabular}{|r|}
96,7 \\
147,5 \\
118,6 \\
62,2 \\
20,7 \\
2,7 \\
27,6 \\
11,5 \\
4,6 \\
0,0 \\
6,0 \\
4,4 \\
4,6 \\
5,7 \\
\end{tabular} & $\begin{array}{r}22,2 \\
69,3 \\
150,5 \\
104,7 \\
10,4 \\
41,8 \\
1,3 \\
24,8 \\
2,6 \\
2,6 \\
5,2 \\
3,9 \\
14,4 \\
\end{array}$ & $\begin{array}{r}108,6 \\
133,4 \\
128,3 \\
79,8 \\
17,0 \\
39,2 \\
71,8 \\
11,7 \\
7,3 \\
9,3 \\
7,1 \\
44,5 \\
\end{array}$ & $\begin{array}{r}29,7 \\
74,3 \\
145,1 \\
48,6 \\
81,1 \\
41,8 \\
55,4 \\
2,7 \\
9,4 \\
8,4 \\
2,6 \\
29,7 \\
29,7 \\
\end{array}$ & 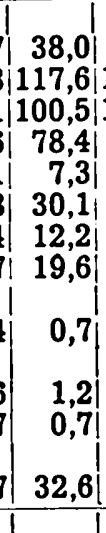 & 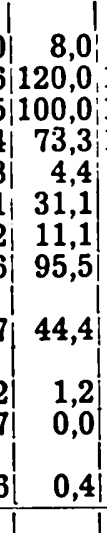 & 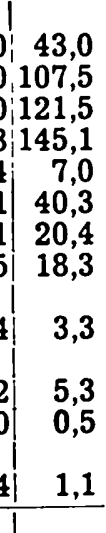 \\
\hline 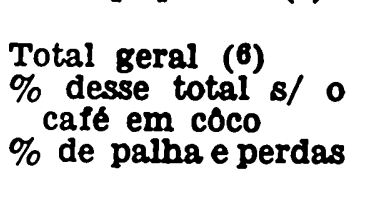 & $\begin{array}{r}610,5 \\
61,0 \\
39,0 \\
\end{array}$ & $\begin{array}{l}- \\
=\end{array}$ & & & & $\begin{array}{l}46,5 \\
53,5 \\
\end{array}$ & & $\mid \begin{array}{l}48,2 \\
51,8\end{array}$ & & & & & $\mid$\begin{tabular}{|l|}
49,2 \\
50,8
\end{tabular} & $\left|\begin{array}{l}48,5 \\
51,55\end{array}\right|$ & $\begin{array}{rl}434,8 & 5 \\
43,4 & 5 \\
56,6\end{array}$ & $\begin{array}{r}573,6 \\
57,4 \\
42,6\end{array}$ & $\begin{array}{r}535,1 \\
53,5 \\
46,5\end{array}$ & $\begin{aligned} 454,91 \\
454,9 \\
45,5 \\
54,5\end{aligned}$ & $\begin{array}{l}51,2,5 \\
51,9 \\
48,1\end{array}$ & & $\begin{array}{r}|604,7| \\
60,5 \\
39,5\end{array}$ & $\begin{array}{l}556,0 \\
55,6 \\
44,4\end{array}$ & 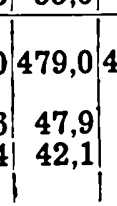 & $\begin{array}{l}485,7 \\
48,6 \\
51,4\end{array} \mid$ & $\begin{array}{l}442,8 \\
44,3 \\
55,7\end{array}$ & $\begin{array}{r}571,3 \\
57,1 \\
42,9\end{array}$ & $\begin{array}{r}536,2 \\
53,6 \\
46,4\end{array}$ & $\begin{array}{l}441,7 \\
44,2 \\
55,8\end{array}$ & $\left|\begin{array}{r}508,6 \\
50,8 \\
49,2\end{array}\right|$ & $\begin{array}{l}488,5 \\
48,8 \\
51,2\end{array}$ & $\begin{array}{l}622,7 \\
62,3 \\
37,7\end{array} \mid$ & 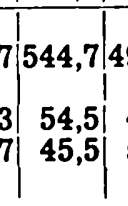 & \begin{tabular}{|l|}
$\mid 497,2$ \\
49,7 \\
50,3
\end{tabular} \mid & $\mid \begin{array}{l}506,1 \\
50,6 \\
49,4\end{array}$ & $\mid \begin{array}{l}\mid 451,1 \\
45,1 \\
54,9\end{array}$ & $\mid \begin{array}{l}594,5 \\
59,4 \\
40,6\end{array}$ & $\mid \begin{array}{l}\mid \\
546,1 \\
54,6 \\
45,4\end{array}$ & 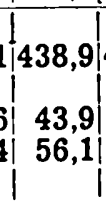 & & $\begin{array}{l}4513,3 \\
91,3 \\
918,7\end{array}$ \\
\hline
\end{tabular}

(1) - $O$ beneficiamento de todas estas produçðes foi realizado, ate 1938, com a "Máquina S. Paulo", tipo 2, cuja classificacho deling compre multo a desejar, em consequencla do que a propres au em diante.

(2) - Café miudo, muito ordinário, com grande proporçăo de grăos pretos, fazendo exceço em algumas safras como a de 1934 .

(3) - "Repasse das peneiras grandes", - onde predominam de modo quase absoluto as "conchas".
(4) - "Cabeça", - café constituldo de um pouco de "mo" grande e principalmente, de "conchas"

(5) - "Repase das peneiras pequenas" era constituido de café muito ordinário com predominancia de grãos pretos. (6) - O "Total Geral" inclui os "coquinhos" não beneiciados.

(7) - Ano de falha total para esta variedade.

(8) - Náo houve colheita para esta experiéncia em 1939 em virtude de extraordinária "chuva de pedras", que em FeDe 1940 , em diante não só o beneficiamento fol realisado com outra máquina a de $\mathrm{n}^{0} .1$ como os talhões desta exp. entram em declinio manifesto de produção e de vigor em consequêncla de crecente invasão de tiririca. Como não é possivel um ajustamento perfeito entre os últimas tipos produzidos pela nova maquina e os da antiga, o "mludo" de nosso quadro ficou sendo a soma do "escolha" e do "expurgo da 1.a classificaçāo", que não existiam na antiga. Os tıpos, porém, que mais importam (peneiras 15 a $19 \mathrm{e}$ mocas) não sofrem alteração, já que para a peneira 15 atribulmos a soma desta e das 


\begin{tabular}{|c|c|c|c|c|c|c|c|c|c|c|c|c|c|c|c|c|c|c|c|c|c|c|c|c|c|c|c|c|c|c|c|c|c|c|c|c|c|c|c|c|}
\hline \multirow{2}{*}{$\begin{array}{c}\text { Peneiras ou "tipos" } \\
\text { produzidos }(1)\end{array}$} & \multicolumn{10}{|c|}{ Sumatra } & \multicolumn{10}{|c|}{ Burbon } & \multicolumn{10}{|c|}{ Nacional } & \multicolumn{10}{|c|}{ Amarelo de Botucatú } \\
\hline & 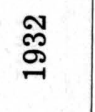 & 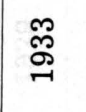 & 芯 & 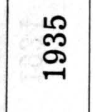 & $\underset{\mathscr{\Omega}}{\stackrel{్}{\rightarrow ~}}$ & 鸽 & 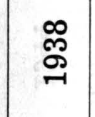 & 导 & કั & 落 & 丳 & 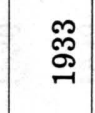 & 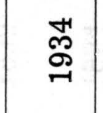 & $\stackrel{\mathscr{m}}{\stackrel{\mathscr{m}}{\rightarrow}}$ & 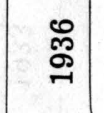 & 桢 & 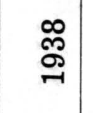 & 윰 & કै & 芯 & ల్య & $\underset{\mathscr{\varpi}}{\stackrel{్}{\sim}}$ & 菏 & 駡 & 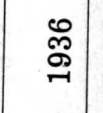 & 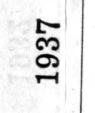 & 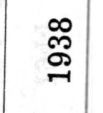 & 异 & ঙ્ & 晜 & 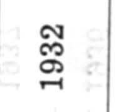 & 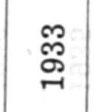 & 范 & 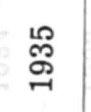 & $\underset{\mathscr{్}}{\mathscr{్}}$ & 駡 & $\underset{\varpi}{\stackrel{్}{్}}$ & 兽 & ঙี & 苛 \\
\hline $\begin{array}{l}\text { Peneiras } 18 \text { e } 19 \text { em } \\
\text { uma só }\end{array}$ & 22,5 & - & 10,1 & 23,3 & 5,3 & 21,6 & 7,8 & 12,2 & 1,4 & 0,7 & 28,1 & 6,1 & 10,4 & 17,3 & 3,9 & 11,7 & 3,7 & 8,5 & 1,4 & 0,9 & 28,3 & 12,0 & 11,5 & 19,3 & 3,7 & 14,4 & 5,9 & 8,4 & 1,3 & 1,8 & $30,7$. & 14,2 & 11,7 & 19,1 & 5,0 & $\begin{array}{ll}0 & 18,1 \\
\end{array}$ & 5,4 & 8,6 & 1,6 & 0,9 \\
\hline Peneira 17 & 27,4 & - & 20,2 & 31,7 & 16,6 & 22,6 & 15,6 & 30,3 & 27,1 & 20,1 & 26,5 & 17,3 & 21,2 & 27,8 & 11,1 & 19,0 & 11,4 & 25,5 & 21,4 & 17,7 & 27,6 & 26,2 & 23,5 & 32,4 & 13,0 & 20,7 & 16,1 & 28,1 & 27,6 & 25,2 & 26,3 & 25,8 & 22,4 & 29,1 & 15,3 & 22,4 & 13,6 & 26,8 & 25,2 & 21,1 \\
\hline Peneira 16 & 21,4 & - & 24,8 & 20,0 & 33,4 & 20,8 & 23,2 & 22,3 & 21,8 & 26,3 & 18,7 & 26,0 & 26,3 & 24,2 & 30,4 & 23,6 & 23,4 & 22,0 & 22,5 & 23,1 & 18,3 & 27,1 & 27,7 & 23,1 & 33,4 & 22,4 & 27,4 & 22,9 & 23,9 & 25,0 & 17,6 & 25,8 & 26,6 & 23,4 & 33,3 & 21,6 & 25,0 & 22,9 & 20,2 & 25,1 \\
\hline Peneira 15 & 6,8 & - & 14,4 & 5,5 & 21,2 & 13,8 & 21,1 & 13,4 & 19,5 & 25,7 & 5,0 & 22,6 & 16,4 & 13,6 & 24,8 & 21,0 & 28,4 & 19,6 & 20,8 & 31,3 & 4,3 & 13,0 & 14,5 & 8,8 & 22,0 & 16,1 & 24,8 & 17,8 & 19,4 & 19,4 & 5,6 & 15,0 & 14,6 & 12,3 & 23,2 & 13,4 & 27,2 & 17,8 & 14,8 & 28,2 \\
\hline Moca 1 & 3,3 & - & 2,7 & 5,5 & 2,0 & 2,9 & 1,3 & 2,8 & 1,0 & 1,3 & 3,6 & 1,5 & 2,8 & 4,3 & 1,2 & 2,4 & 1,1 & 2,0 & 1,2 & 1,5 & 3,4 & 1,5 & 3,1 & 4,7 & 1,9 & 2,1 & 1,7 & 1,8 & 1,1 & 2,1 & 3,1 & 1,8 & 3,2 & 4,1 & 2,3 & 3,0 & 1,5 & 1,7 & 0,9 & 1,3 \\
\hline Moca 2 & 3,0 & - & 5,4 & 4,5 & 7,8 & 5,3 & 4,5 & 5,2 & 5,7 & 7,0 & 3,0 & 3,1 & 6,8 & 6,2 & 7,9 & 6,4 & 6,4 & 6,0 & 6,5 & 7,3 & 2,7 & 4,0 & 2,0 & 6,9 & 8,6 & 6,3 & 7,0 & 5,4 & 7,5 & 10,3 & 3,4 & 4,3 & 7,8 & 5,5 & 9,2 & 6,6 & 7,6 & 6,8 & 6,3 & 7,9 \\
\hline Moca 3 & 0,4 & - & 0,9 & 06 , & 0,2 & 1,0 & 8,1 & 1,6 & 2,6 & 3,2 & 0,3 & 0,5 & 1,5 & 2,4 & 0,3 & 1,6 & 12,3 & 2,7 & 2,8 & 4,4 & 0,2 & 0,1 & 1,3 & 1,6 & 0,3 & 1,5 & 7,2 & 2,4 & 2,8 & 2,9 & 0,2 & 0,2 & 1,4 & 2,3 & 0,2 & 1,3 & 10,1 & 2,8 & 2,2 & 4,0 \\
\hline Miudo & 2,4 & - & 1,7 & 1,1 & 3,5 & 2,0 & 1,4 & 3,3 & 10,1 & 9,3 & 1,8 & 5,1 & 2,6 & 0,9 & 3,6 & 3,3 & 0,5 & 4,1 & 12,3 & 5,8 & 1,6 & $\begin{array}{r}2,6 \\
\end{array}$ & 1,7 & 0,4 & 3,1 & 2,5 & 0,2 & 4,7 & 7,3 & 3,2 & $2, \overline{1}$ & 3,0 & 1,8 & 0,9 & 5,3 & 2,0 & $\begin{array}{l}0,5 \\
\end{array}$ & 4,5 & 19,3 & 3,5 \\
\hline $\begin{array}{l}\text { Repasse das penei- } \\
\text { ras grandes }\end{array}$ & 2,1 & - & 2,8 & 0,0 & 0,0 & 1,0 & 1,1 & 0,2 & 10,2 & 5,9 & 0,5 & 1,2 & 1,8 & 0,0 & 2,5 & 1,4 & 1,4 & 0,1 & 10,2 & 6,7 & 0,6 & 1,4 & 2,3 & $0,0 \mid$ & 1,8 & 2,1 & 1,2 & 0,2 & 8,9 & 10,0 & $\Omega, 4$ & 1,1 & 1,6 & 0,0 & 0,5 & 1,2 & 1,7 & $0,2\}$ & 9,0 & 6,6 \\
\hline $\begin{array}{l}\text { “ Coquinhos" nã o } \\
\text { beneficiados }\end{array}$ & 1,3 & - & 0,6 & 1,1 & 0,7 & 1,3 & 1,4 & 0,1 & 0,1 & 0,3 & 1,3 & 1,2 & 0,8 & 1,4 & 0,9 & 1.4 & 1,8 & 0,1 & 0,5 & 1,1 & 1,4 & \begin{tabular}{|l|} 
\\
\end{tabular} & 0,8 & 0,9 & \begin{tabular}{|l|} 
\\
\end{tabular} & 1,4 & 1,0 & 0,1 & 0,1 & 0,1 & 1,3 & 1,1 & $0,9 \mid$ & 1,3 & $1,0 \mid$ & 1,6 & 1,5 & 0,3 & 0,3 & 1,0 \\
\hline Cabeça & 0,4 & - & 0,0 & 1,1 & 0,4 & 1,3 & 0,6 & 0,2 & $0 ; 0$ & 0,0 & 2,5 & 0,1 & 0,0 & 0,9 & 0,6 & 1,2 & 0,5 & 0,1 & 0,1 & 0,0 & 2,2 & 0,1 & 0,0 & 0,9 & 0,6 & 1,0 & 0,5 & 0,1 & 0,0 & 0,0 & 2,3 & 0,1 & 0,0 & 0,9 & 0,8 & 1,3 & 0,5 & 0,2 & 0,0 & 0,1 \\
\hline \multirow[t]{2}{*}{$\begin{array}{l}\text { Repasse das penei- } \\
\text { ras pequenas }\end{array}$} & 8,9 & - & 16,3 & 5,5 & 8,6 & 6,3 & 13,8 & 8,3 & 0,1 & 0,1 & 8,4 & 15,0 & $\mid 9,6$ & 1,1 & 12,7 & 7.0 & 8,8 & 9,0 & 0,2 & 0,1 & 9,1 & $\mid 11,1$ & 11,5 & 0,4 & 10,5 & 9,2 & 7,0 & 7,6 & 0,1 & 0,0 & 6,7 & 7,6 & 7,8 & 1,1 & 3,1 & 7,5 & 5,4 & 7,3 & 0,1 & 0,2 \\
\hline & 99,9 & - & 99,9 & 99,9 & 99,7 & 99,9 & 99,9 & 99,9 & 99,6 & 99,9 & 99,7 & $|99,7|$ & $|100,2| 1$ & 100,1 & $|99,9| 1$ & 100,0 & 99,7 & 99,7 & 99,9 & 99,9 & 99,7 & 99,9 & 99,9 & 99,4 & 99,8 & 99,61 & 100,0 & 99,51 & 100,01 & 100,0 & 99,71 & 100,0 & \begin{tabular}{ll|l}
99,8 & 10
\end{tabular} & 100,0 & $99,2 \mid 1$ & $100,0 \mid 1$ & $\mid 100,0$ & 99,9 & 99,9 & 99,9 \\
\hline
\end{tabular}




\begin{tabular}{|c|c|c|c|c|c|c|c|c|c|c|c|c|c|c|c|c|c|c|c|c|c|c|}
\hline \multirow{2}{*}{.$\quad}$. & \multicolumn{11}{|c|}{ Sumatra } & \multicolumn{11}{|c|}{ Burbon } \\
\hline & జ్ఞ & $\stackrel{\mathscr{ஜ}}{\underset{\Xi}{\Phi}}$ & $\underset{\varpi}{\rightleftarrows}$ & $\stackrel{\mathscr{m}}{\mathrm{g}}$ & $\underset{\mathscr{\varpi}}{\mathscr{\sigma}}$ & ळ్య & $\underset{\check{\varpi}}{\infty}$ & 品 & $\underset{\sim}{\stackrel{\sim}{\rightleftarrows}}$ & 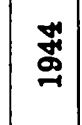 & 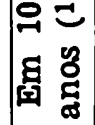 & 总 & 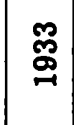 & $\stackrel{\not ̈}{\mathscr{g}}$ & $\stackrel{\mathscr{\varpi}}{\stackrel{\varpi}{二}}$ & $\underset{\mathscr{\varpi}}{\mathscr{\varpi}}$ & ळ్య & $\underset{\mathscr{\varpi}}{\stackrel{్}{్}}$ & 导 & 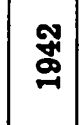 & 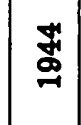 & 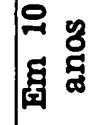 \\
\hline $\begin{array}{l}\% \text { das } 5 \text { prmeiras peneiras sobre o café em coco } \\
\% \text { das "Mocas" }\end{array}$ & $\begin{array}{r}47,8 \\
4,0 \\
\end{array}$ & $=1$ & $\left|\begin{array}{r}36,6 \\
4,7\end{array}\right|$ & $\mid \begin{array}{r}42,3 \\
5,5\end{array}$ & $\begin{array}{r}36,9 \\
4,9\end{array}$ & $\mid \begin{array}{r}36,6 \\
4,3\end{array}$ & $\begin{array}{r}37,7 \\
7,8\end{array}$ & $\begin{array}{r}37,7 \\
4,7\end{array} \mid$ & $\left|\begin{array}{r}40,6 \\
5,3\end{array}\right|$ & $\left|\begin{array}{r}37,4 \\
5,6\end{array}\right|$ & $\begin{array}{r}39,3 \\
5,2\end{array}$ & $\begin{array}{r}48,3 \\
4,3\end{array}$ & $\left|\begin{array}{r}37,9 \\
2,7\end{array}\right|$ & $\left|\begin{array}{r}36,6 \\
5,5\end{array}\right|$ & $\left|\begin{array}{r}40,0 \\
6,3\end{array}\right|$ & $\mid \begin{array}{r}30,8 \\
4,1\end{array}$ & $\mid \begin{array}{r}43,0 \\
6,0\end{array}$ & $\left|\begin{array}{l}35,8 \\
10,6\end{array}\right|$ & $\begin{array}{r}34,4 \\
4,9\end{array}$ & $\begin{array}{r}34,3 \\
5,4\end{array}$ & $\left|\begin{array}{r}36,4 \\
6,5\end{array}\right|$ & \begin{tabular}{r|r}
4 & 37,7 \\
5 & 5,7
\end{tabular} \\
\hline 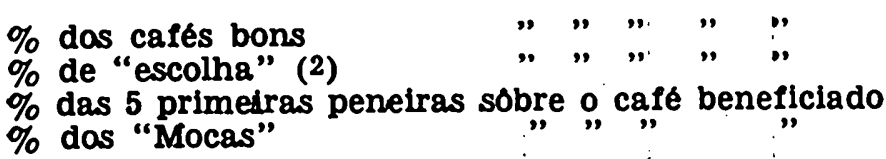 & $\begin{array}{r}51,8 \\
9,2 \\
78,1 \\
6,7 \\
\end{array}$ & 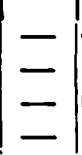 & $\left|\begin{array}{r}41,3 \\
11,3 \\
69,5 \\
9,0\end{array}\right|$ & $\left|\begin{array}{r}48,8 \\
4,6 \\
80,5 \\
10,6\end{array}\right|$ & $\begin{array}{r}41,8 \\
6,5 \\
76,5 \\
10,0\end{array}$ & $\left|\begin{array}{r}40,9 \\
5,6 \\
78,8 \\
9,2\end{array}\right|$ & $\left|\begin{array}{l}45,5 \\
10,2 \\
67,7 \\
13,9\end{array}\right|$ & $\left|\begin{array}{r}42,4 \\
5,8 \\
78,2 \\
9,6\end{array}\right|$ & $\begin{array}{r}45,9 \\
12,3 \\
69,8 \\
9,3\end{array}$ & $\left|\begin{array}{r}43,0 \\
6,2 \\
72,8 \\
11,5\end{array}\right|$ & $\begin{array}{r}44,5 \\
7,9 \\
74,6 \\
10,0\end{array}$ & $\begin{array}{r}52,6 \\
9,0 \\
78,3 \\
6,9\end{array}$ & $\left|\begin{array}{r}40,6 \\
11,9 \\
72,2 \\
5,1\end{array}\right|$ & $\left|\begin{array}{r}42,1 \\
7,1 \\
74,3 \\
11,1\end{array}\right|$ & $\left|\begin{array}{r}46,3 \\
2,2 \\
82,9 \\
12,9\end{array}\right|$ & $\mid \begin{array}{r}34,9 \\
8,6 \\
70,2 \\
9,4\end{array}$ & $\begin{array}{r}49,0 \\
8,4 \\
75,3 \\
10,4\end{array}$ & $\left|\begin{array}{r}46,4 \\
7,1 \\
66,9 \\
19,8\end{array}\right|$ & $\begin{array}{r}39,3 \\
5,7 \\
75,6 \\
10,7\end{array}$ & $\begin{array}{l}39,7 \\
12,2 \\
66,1 \\
10,5\end{array}$ & $\mid \begin{array}{r}42,9 \\
7,1 \\
73,0 \\
13,2\end{array}$ & \begin{tabular}{|r|r}
9 & 43,4 \\
1 & 7,9 \\
0 & 73,5 \\
2 & 11,0
\end{tabular} \\
\hline 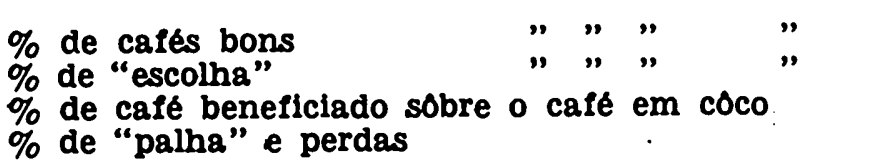 & $\begin{array}{l}84,8 \\
15,1 \\
61,0 \\
39,0\end{array}$ & $\begin{array}{l}- \\
- \\
-\end{array}$ & $\mid \begin{array}{l}78,5 \\
21,4 \\
52,6 \\
47,4\end{array}$ & $\begin{array}{r}91,1 \\
8,8 \\
52,4 \\
47,6\end{array}$ & $\begin{array}{l}86,5 \\
13,4 \\
48,3 \\
51,7\end{array}$ & $\begin{array}{l}88,0 \\
11,9 \\
46,5 \\
53,5\end{array}$ & $\begin{array}{l}81,6 \\
18,3 \\
55,5 \\
44,5\end{array}$ & $\mid \begin{array}{l}87,8 \\
12,1 \\
48,2 \\
51,8\end{array}$ & $\left|\begin{array}{l}79,1 \\
20,8 \\
58,2 \\
41,8\end{array}\right|$ & $\begin{array}{l}84,3 \\
15,7 \\
49,2 \\
50,8\end{array}$ & $\begin{array}{l}84,6 \\
15,3 \\
52,4 \\
47,6\end{array}$ & $\begin{array}{l}85,2 \\
14,8 \\
61,5 \\
38,5\end{array}$ & $\mid \begin{array}{l}77,3 \\
22,6 \\
52,4 \\
47,6\end{array}$ & $\begin{array}{l}85,4 \\
14,7 \\
49,2 \\
50,8\end{array}$ & $\begin{array}{r}95,8 \\
4,3 \\
48,5 \\
51,5\end{array}$ & $\left\{\begin{array}{l}79,6 \\
20,3 \\
43,4 \\
56,6\end{array}\right.$ & $\left|\begin{array}{l}85,7 \\
14,3 \\
57,4 \\
42,6\end{array}\right|$ & $\left|\begin{array}{l}86,7 \\
13,3 \\
53,5 \\
46,5\end{array}\right|$ & $\begin{array}{l}86,3 \\
13,6 \\
45,0 \\
55,0\end{array}$ & $\mid \begin{array}{l}76,6 \\
23,3 \\
51,9 \\
48,1\end{array}$ & $\begin{array}{l}86,2 \\
13,7 \\
50,0 \\
50,0\end{array}$ & 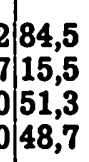 \\
\hline & & & & & $\mathrm{Na}$ & cions & & & & & & & & & Amar & relo & de $B$ & Botuc & catú & & & \\
\hline $\begin{array}{l}\% \text { das } 5 \text { primeiras peneiras sobre o café em côco } \\
\% \text { das "Mocas" }\end{array}$ & $\begin{array}{r}47,5 \\
3,8 \\
\end{array}$ & $|43,7|$ & $|37,0|$ & $|40,7|$ & $\begin{array}{l}32,0 \\
4,8 \\
\end{array}$ & $\mid 42,1$ & $|39,8|$ & $|34,3| ;$ & $\mid \begin{array}{l}\mid 36,5 \\
\mid 5,7\end{array}$ & $|35,2|$ & $\begin{array}{r}38,8 \\
5,1\end{array}$ & $\begin{array}{r}50,0 \\
4,2\end{array}$ & $\begin{array}{r}43,8 \\
3,5 \\
\end{array}$ & $\begin{array}{r}37,5 \\
6,2\end{array}$ & $\begin{array}{r}42,5 \\
6,0 \mid \\
\end{array}$ & $\begin{array}{r}34,7 \\
5,3 \\
\end{array}$ & $\begin{array}{r}45,0 \\
6,4\end{array} \mid$ & $\left|\begin{array}{l}38,8 \\
10,5\end{array}\right|$ & $\left|\begin{array}{r}33,4 \\
5,1\end{array}\right|$ & $\mid \begin{array}{r}30,5 \\
4,6\end{array}$ & $\mid \begin{array}{r}37,8 \\
6,7\end{array}$ & \begin{tabular}{|r|r}
839,4 \\
7 & 5,8
\end{tabular} \\
\hline $\begin{array}{l}\% \text { das cafés bons } \\
\% \text { de "escolha" }\end{array}$ & $\begin{array}{r}51,4 \\
9,0 \\
78,5 \\
6,3\end{array}$ & $\mid \begin{array}{r}46,8 \\
8,8 \\
78,3 \\
5,6\end{array}$ & $\begin{array}{r}40,1 \\
7,8 \\
77,2 \\
6,4\end{array} \mid$ & $\left|\begin{array}{r}47,2 \\
1,4 \\
83,6 \\
13,4\end{array}\right|$ & $\begin{array}{r}36,8 \\
7,5 \\
72,1 \\
10,8\end{array}$ & $\mid \begin{array}{r}47,8 \\
9,3 \\
73,6 \\
9,9\end{array}$ & $\left|\begin{array}{r}48,3 \\
5,3 \\
74,2 \\
15,9\end{array}\right|$ & $\begin{array}{r}38,5 \\
5,8 \\
77,2 \\
9,6\end{array}$ & $\begin{array}{r}42,2 \\
8,3 \\
72,2 \\
11,4\end{array}$ & $\begin{array}{r}39,8 \\
9,1 \\
71,4 \\
15,3\end{array}$ & $\begin{array}{r}43,9 \\
7,2 \\
75,8 \\
10,4\end{array}$ & $\begin{array}{r}54,2 \\
8,1 \\
80,2 \\
6,7\end{array}$ & $\mid \begin{array}{r}47,3 \\
7,2 \\
80,8 \\
6,3\end{array}$ & $\begin{array}{r}43,7 \\
6,0 \\
75,3 \\
12,4\end{array}$ & $\left|\begin{array}{r}48,5 \\
2,1 \\
83,9 \\
11,9\end{array}\right|$ & $\begin{array}{r}40,0 \\
5,1 \\
76,8 \\
11,7\end{array}$ & $\begin{array}{r}51,4 \\
8,0 \\
75,5 \\
10,9\end{array}$ & $\begin{array}{r}49,3 \\
5,3 \\
71,2 \\
19,2\end{array}$ & $\begin{array}{r}38,5 \\
5,4 \\
76,1 \\
11,3\end{array}$ & $\begin{array}{r}35,1 \\
4,2 \\
61,8 \\
9,4\end{array}$ & $\begin{array}{r}44,5 \\
5,9 \\
75,3 \\
13,2\end{array}$ & \begin{tabular}{|r|r}
5 & 45,2 \\
9 & 5,7 \\
35,7 \\
2 & 10,6
\end{tabular} \\
\hline 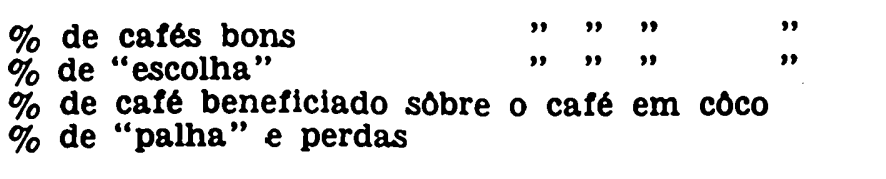 & $\begin{array}{l}84,8 \\
14,8 \\
60,5 \\
39,5\end{array}$ & $\begin{array}{l}83,9 \\
16,0 \\
55,6 \\
44,4\end{array}$ & $\begin{array}{l}83,6 \\
16,3 \\
47,9 \\
42,1\end{array}$ & $\left|\begin{array}{r}97,0 \\
2,8 \\
48,6 \\
51,4\end{array}\right|$ & $\begin{array}{l}82,9 \\
16,9 \\
44,3 \\
55,7\end{array}$ & $\mid \begin{array}{l}83,5 \\
16,5 \\
57,1 \\
42,9\end{array}$ & $\mid \begin{array}{r}80,1 \\
9,9 \\
53,6 \\
46,4\end{array}$ & $\mid \begin{array}{l}86,8 \\
12,9 \\
44,3 \\
55,7\end{array}$ & $\begin{array}{l}83,6 \\
16,4 \\
50,5 \\
49,5\end{array}$ & $\begin{array}{l}86,7 \\
13,3 \\
48,9 \\
51,1\end{array}$ & $\begin{array}{l}86,2 \\
13,6 \\
51,1 \\
48,9\end{array}$ & $\begin{array}{l}86,9 \\
12,8 \\
62,3 \\
37,7\end{array}$ & \begin{tabular}{|l|}
87,1 \\
12,9 \\
54,5 \\
45,5
\end{tabular} & \begin{tabular}{|l|}
87,7 \\
12,1 \\
49,7 \\
50,3
\end{tabular} & $\left|\begin{array}{r}95,8 \\
4,2 \\
50,6 \\
49,4\end{array}\right|$ & $\begin{array}{l}88,5 \\
10,7 \\
45,1 \\
54,9\end{array}$ & \begin{tabular}{|l|}
86,4 \\
13,6 \\
59,4 \\
40,6
\end{tabular} & $\begin{array}{r}90,4 \\
9,6 \\
54,6 \\
45,4\end{array}$ & $\begin{array}{l}87,4 \\
12,6 \\
43,9 \\
56,1\end{array}$ & $\left\{\begin{array}{l}71,2 \\
28,8 \\
49,3 \\
50,7\end{array}\right.$ & $\begin{array}{l}88,5 \\
11,5 \\
50,4 \\
49,6\end{array}$ & \begin{tabular}{c|c}
5 & 86,3 \\
5 & 13,6 \\
4 & 51,9 \\
$8 \mid 48,1$
\end{tabular} \\
\hline
\end{tabular}

(1) - Para o "Sumatra" somente 9 anos. Em todos as casos, fra çóes uproximadas.

(2) - Estamos chamando de "escolha" todo o café beneficiado que não se enquadra nos dois grupos precedentes, incluindo, portanto, o "re passe das peneiras grandes"; melhor conviria o titulo de "cafés inferiores". 
Durantle os 7 primeiros anos (1) (médias)

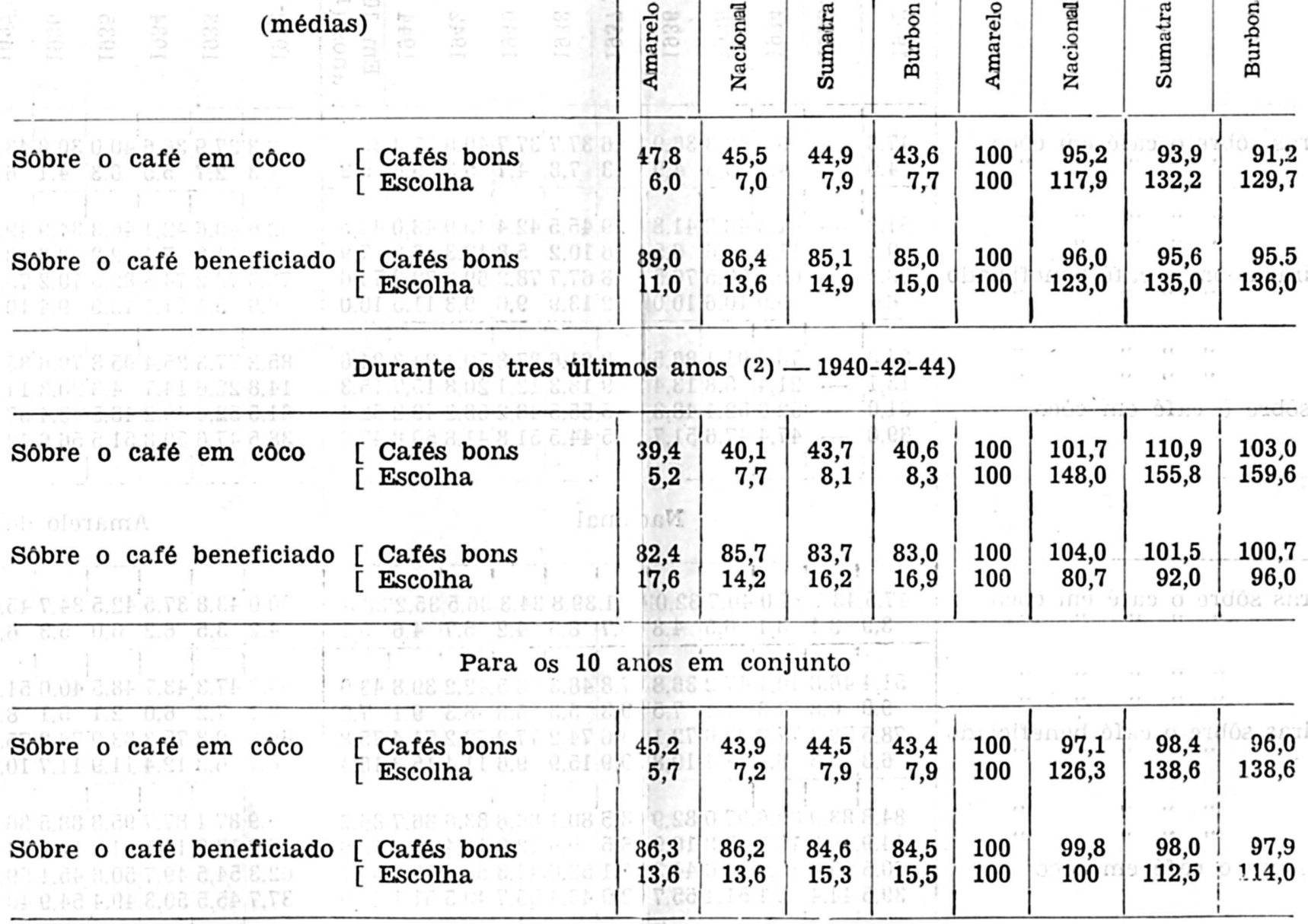

(1) - Cafezal em pleno vigor (de 7 a 14 anos de idade) e beneficiamento pela primeira máquina.

(2) - O segundo período, abrangendo os tres últimos anos dêste trabalho, é aqui estudado separadamente em consequência do declínio do "Nacional", do "Burbon” e, especialmente, do "Amarelo de Botucatú", pelos motivos expostos no texto; além dêsse motivo, o fato de terem sido essas tres safras beneficia das na segunda máquina - a "S. Paulo N. 1". 
mais ainda, "nem como forma, se justifica a descriçăo do cafe "Sumatra", menos ainda como variedade (3).

Finalizamos esta primeira parte, estudando o "rendimento" liquido ie proporcional da soma de todos os cafés vendáveis, conjunto que pimas chamando de "caftes bons".

Analisando o Quadro V, verificamos que o "Amarelo de Botucatū" suplantou os très rivals na média das sete primeiros anos desta experiêncla, isto é, enquanto as plantas, $\nabla 1$ vendo de seu $7 .^{\circ}$ ao $14 .^{\circ}$ anas de existencia, revelavam pleno vigor. A mesma variedade é destronada de sua superioridade no conjunto dos tres anos que se seguem, especialmente pelo "Nacional", fato esse que pode ser interpretado de dols modas:

1.0) - Porque n5o fizemos observaç⿸丆es continuas durante este segundo periodo e o acaso poderla ter contribuido com conđiçōes menos favoráveis para essa variedade nos anas de 1940, 42 e 44;

2.0) - Porque, e ẽ o mais provável, sendo êle reconhecidamente mais sensivel, cultivado em terra gasta, como fol, patenteou seu declinio mais ràpidamente que os demais; vem ao encontro desta suposição o fato de o "Burbon" o acompanhar nessa mesma manifestaçăo, como "um fidalgo que exige tratamento de fidalgo", no dizer de Dafert.

o "Amarelo" só foi realmente superado pelo "Nacional". sabidamente 0 mats rústico de todos.

Para o conjunto de dez anos năo se constatam diferenças ponderáveis, $o$ que provavelmente é a consequencia de um periodo longo de vigor e pequeno de decadencia, resultados esses que năo invalidam a conclusăo precedente.

Quanto à correlação que passa existir entre o "tipo" ou, melhor, tamanho das sementes e a "bebida", é preciso discutir a questăo com um pouco mais de detalhes do que temos feito até aqui, na falta de elementos mais positivas.

A primeira vista, e de um modo geral, colhemas a impressão que năo existe correlaçăo alguma entre esse tamanho e a bebida, como provam os exemplos que vamos enu-

(3) - C. A. Krug, J. E, T. Mendes e Alodies de Carvalho - "Traxonomila die Coffea anabica L." $1938-19$ e 20 . 
zerar, deduzidas todas de nossas experiências, realizadas, aliás, visando outros objetivos: (4)

1.) - Em uma experiência, na qual procurávamos vislumbrar diferenças de "bebida" entre os produtos das quatro variedades que vinhamos estudando, tanto encontrámos a bebida "dura" para as "mocas" como para as peneiras $16 \mathrm{e}$ 18, fato êsse que se repete em outras experiências sôbre fermentações;

2.0) - Em outra, sóbre os efeitos de sombreamento, tanto produziram bebida "dura" as peneiras 16 e 18, em uns casos, como o "estritamente mole", em outros. Tanto revelou essa mesma bebida "estritamente mole", um de peneira 18, tipo 3, como um seu irmå, classficado como $4+10$;

3.0) - Em outro trabalho, encontramos o qualificativo de "mole bôa" para um café tipo 2, peneira $171 / 2$ e igual dienominação para o respectivo "moca". classificado como 6-20. Do mesmo modo, tanto produziu "simplesmente mole" um "chato tipo 2", como seu correspondente rem tratamento, tipo 7. E mais notável ainda: nessa mesma experiencia encontrámas dois lotes "estritamente mole", tanto para a peneira 18, tipo 2, como para suas respectivas "escolhas";

4.9) - Em uma experiência sôbre adubaçóes, encontrámos, para o mesmo tratamento, a biebida "mole" para o tipo 6 e a de "Rio" para o 6-25;

5.0) - O exemplo que mais nos deixa em dúvida provém de uma experiência na qual estudávamas diversos tipas de seca. Ai encontrámos, em 5 casos, a bebida diretamente correlacionada com o tipo, em outras 5, indiferente, $\mathrm{e}$, coùsa curiosa, dois de resultados contraditórios: em uma delas, o "escolha", trazendo como nota de "abaixo" de qualquer classificação, como possuidora de melhor bebida que o seu respectivo tipo 3, e outra - um despolpado, no qual o tipo 7 obteve "iestritamente mole", ao passo que o seu tipo 3 só obteve "mole".

(4) - Devemos lembrar que todos os trabalhos de classificação foram realizados pela Secção de Classificação do antigo Instituto do Café de Sãc Paulo, hoje "Superitendência dos Serviços do Café", da Secretaria da Fazendı, aos funcionários da qual, especialmente ao $\mathrm{Sr}$. José Largacha, agrádecemos a solicitude com que sempre nos atenderam. 
Dispensável será dzer que só comparámos cafés tratadas em perfeita igualdade de condições, muitas vezes somente separados por peneiras ou à mão, depols de beneficiados.

Poderiamos ainda prolongar êstes exemplos, demonstrando que nåo existe uma correlação obrigatória entre o tamanho ou "tipo da semente" e sua cornespondente "bebida". Este fenômeno patentea-se principalmente nos extremos: quando a bebida é realmente "estritamente mole", ela se releva na maioria dos casos, em todos as tipos ou, em posiçăo opasta, quando é caracteristicamente "dura" ou "Rio", afeta igualmente todos as tamanhos. $E$ ' que evidentemente, fatores outras sobrelevam o valor do tamanho das sementes, como sejam as qualidades intrínsecas dos frutos e das condições extrínsecas que presidem seu secamento, meio e modo.

Não se poderá, contudo, negar que a não ser nesses casos, e mesmo em muitos dentre eles, pode e deve haver alguma correlação entre essas duas manifestaçóes biológicas, especialmente quando a classificação e seu complemento "catação" forem rigorosos; do contrário, a maior ou menor presença de "pretos" ou de sementes pequenas, mirradas, produto de frutos colhidos verdes, pode e deve afetar diversamente o paladar do lote em que se fizeram notar, mascarando qualquer passfivel correlação entre o tamanho e gósto.

Que essa correlação pode existir demonstra-o o Quadro VII, que aqui damas com detalhes porque é elucidativo.

Náo tem êsse quadro, nesta experiência, o fim de colocar em destaque a superioridade de uns tratamentas em relaçăo a outros. Visamas tăo sòmente, mastrar que a simples separaçáo por peneiras, pode nevelar em um mesmo lote, bebidas diversas, mostrando aquela correlaçăo de que atrés falamas.

Cada lote, de um mesmo tratamento, foi separado em duas partes: uma retida acima da peneira 15, sem outra separaçăo, e outra que lhe ficava abaixo, reunindo as cafés menores, quebrados, bichados, escoimados, porém, de outras impurezas. A esta fraçro demas o nome de "escolha", sem o ser muitas vezes, como no caso dos cafés despolpadas. A correlação entre a "bebida" e essas duas fraçóes é evidente em oito casos sôbre os onze estudados. 
Poderíamas repetir o exempio com outros trabalhos nosi quais se patentieia a citada correlação, a despeito de arguns casos contraditórios.

Conclusão - Concluimos que se não exíste uma correla̧ão obrigatória entre tamanho das sementes e sua "bebiđa": - mais natural é que iessa correlação deva existir na gene-ralidade dos casos, maximé quando a classificação fôr perfeita, năo permitindo assím a mistura de "tipos" que podem provir de estados diversos de maturação, đa sẽca, ou da fermentaçăo dos frutos. A diversidade de tamanhos pode também afetar a uniformidade da "torração".

Daí se concluír que os tipos finos devem ser escoimados. das defeitos que, afetando seu aspecto; mais as lesvalorizam diminuindo suas qualidades gustativas.

Concluimas êste artigo voltanđo à questäo đas variaçס̄es de produção do cafeeiro.

Tódas as variedađes, umas maís, outras menas, revelam, đurante o decorrer de sua vida, oscilaçōes de produção, muitas vezes notáveis. Fenómeno inconteste, sobejamente constatado na prática, explica-se satisfatóriamente pelo fato de se saber que "o cafeeiro só frutifica em ramo đo ano passado", isto é, em ramos que despontaram com a primavera, se đesenvolveram durante 0 início do verăo do ano anterior e mais ainda do próprio em que se vaí realizar a frutifícação. Durante a primavera e o verão crescem em comprimento as galhos, no outono amadurecem e se preparam para o flonescimento. Mais que nos climas temperados, o nosso, fugindo ao rigorismo astronômico, permite uma primavera antecipada, se não sobrevierem sécas excessivas. Estas, então, vão desempenhar papel de destaque no modo de florescer do cafeetro e no de preparar a futura produçāa.

Ora, qualquer que seja o solo ou a idade da planta, desde que năo revelem declínio acentuado de fertilidade o primeiro, ou de vigor a segunda, nesta vão se refletir as fenómenos que condicionam o crescimento de seus ramos e, consequentemente, a ano favorável deve, futuramente, corresponder maior produção, supostos iguais todos os demais fatores, đentre os quais desempenha papel de relêvo o decorrer do inverno (Junho-Setembro) durante o qual vai se preparar e se processar o florescimento, fenómenos ésses condicionadas à fi- 
QUADRO VI

Relaçōes entre a produção, tipos e o decorrer das estaçôes

\begin{tabular}{|c|c|c|c|c|c|c|c|c|c|c|c|c|c|c|c|c|c|c|c|c|c|c|c|c|c|c|c|c|c|c|c|}
\hline \multirow[b]{2}{*}{$\begin{array}{l}\text { Anos } \\
\text { agricolas }\end{array}$} & \multicolumn{4}{|c|}{$\begin{array}{c}\begin{array}{c}\text { Produçōes relativas de } \\
\text { café em coco (1) }\end{array} \\
\end{array}$} & \multicolumn{4}{|c|}{$\begin{array}{r}\text { Rendimento no } \\
\text { beneficiamento } \\
\text { (2) } \%\end{array}$} & \multicolumn{4}{|c|}{$\begin{array}{c}\text { Produçōes relativas de } \\
\text { cafte beneficiado (3) }\end{array}$} & \multirow{2}{*}{\multicolumn{2}{|c|}{$\begin{array}{l}\text { Chuvas } \\
\text { m. m. }\end{array}$}} & \multicolumn{13}{|c|}{ Distribuiçăo das chuvas segundo as meses } & & & & \\
\hline & 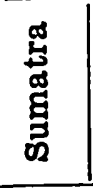 & 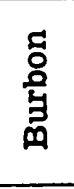 & 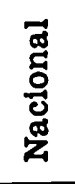 & 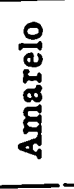 & 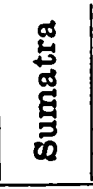 & 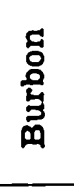 & 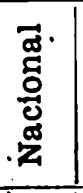 & 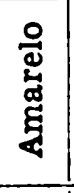 & 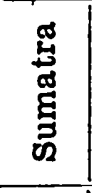 & $\begin{array}{l}\text { ̊̊ } \\
\text { 官 }\end{array}$ & 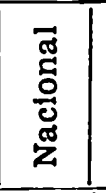 & 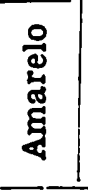 & & & 站 & $\begin{array}{l}8 \\
\text { 总 } \\
\text { of }\end{array}$ & 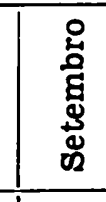 & 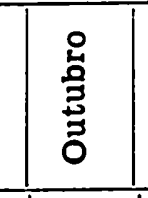 & 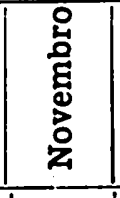 & 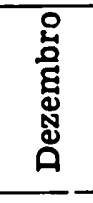 & 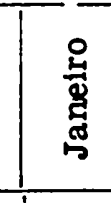 & 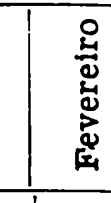 & 总 & 蛋 & & . & 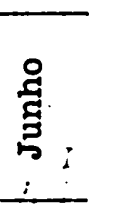 & & & & \\
\hline $1930-31$ & - & -- & - & - & - & - & - & - & - & - & - & - & 17 & & 68,5 & 47,1 & 52,6 & $6 \mid 116,4$ & 108,0 & 328,6 & 324, & \begin{tabular}{l|l|l}
2 & 334 \\
\end{tabular} & \begin{tabular}{l|l}
1,4 & 184,3 \\
\end{tabular} & 103 & & 37,0 & 16,0 & & & & \\
\hline 1931-32 & 100 & 100 & 100 & 100 & 61 & 61 & 60 & 62 & 100 & 100 & 100 & 100 & 12 & 13 & 38,9 & 11,0 & 138, & 65,8 & 214,0 & 149,1 & 204, & 95 & \begin{tabular}{l|l}
5,7 & 123,8 \\
\end{tabular} & 30, & 0,4 & $\mathbf{9 8 , 2}$ & 44,0 & & & & \\
\hline $1932-33$ & 7 & 173 & 44 & 150 & 61 & 52 & 56 & 55 & 7 & 147 & 40 & 133 & 11 & 70 & 4,6 & 46,2 & 48, & 113,4 & 174,8 & 336,4 & 119, & 150 & \begin{tabular}{l|l}
0,0 & 41,6 \\
\end{tabular}$-100$ & 4 & 4,0 & 77,0 & 53,8 & & & & \\
\hline $1933-34$ & 54 & 43 & 45 & 29 & 53 & 49 & 48 & 50 & 47 & 34 & 36 & 23 & 9 & 53 & 7,0 & 15,4 & 50,8 & \begin{tabular}{l|l|}
8 & 109,2 \\
\end{tabular} & $\begin{array}{l}40,1 \\
\end{array}$ & 302,0 & 220, & 103 & \begin{tabular}{l|l}
3,4 & 46,7
\end{tabular} & 21, & 1,6 & 0,0 & 37,9 & & & & \\
\hline $1934-35$ & 14 & 48 & 23 & 61 & 52 & 48 & 49 & 51 & 12 & 38 & 19 & 49 & 12 & 30 & 0,0 & 6,0 & 59,8 & 70,4 & 122,9 & 415,9 & 91, & 194 & \begin{tabular}{l|l}
1,4 & 140,0
\end{tabular} & 68 & 3,8 & 6,8 & 58,8 & & & & \\
\hline $1935-36$ & 73 & 150 & 77 & 122 & 48 & 44 & 44 & 45 & 57 & 109 & 56 & 87 & 12 & 92 & 16,4 & 18,4 & 223, & \begin{tabular}{l|l|}
8 & 211,4 \\
\end{tabular} & 82,0 & 184,7 & 84, & 203 & \begin{tabular}{l|l}
3,4 & 202,4
\end{tabular} & 37 & 7,8 & 25,6 & 2,0 & & & & \\
\hline $1936-37$ & 64 & 95 & 68 & 138 & 46. & 57 & 57 & 59 & 48 & 88 & 64 & 131 & 14 & 11. & 20,8 & 106,4 & 88, & 51,8 & 86,8 & 293,6 & 139, & 95 & $3,8 \mid 206,2$ & 203 & & 74,4 & 46,0 & & & & \\
\hline \multirow[t]{3}{*}{$1937-38$} & 66 & 97 & 87 & 86 & $55^{\circ}$ & 53 & 54 & 55 & 59 & 84 & 76 & 76 & 10 & 37 & 0,0 & 67,0 & 13, & \begin{tabular}{l|l|}
8 & 115,6 \\
\end{tabular} & 121,8 & 141,8 & \begin{tabular}{|l|}
158, \\
\end{tabular} & 120 & $\begin{array}{l}0,6 \\
\end{array} \mid 107,0$ & 66, & 3,0 & 85,5 & 0,0 & & & & \\
\hline & \multirow{2}{*}{\multicolumn{4}{|c|}{ Peneiras 18 e $19(4)$}} & \multirow{2}{*}{\multicolumn{4}{|c|}{ Peneiras 15,16 e 17}} & \multirow{2}{*}{\multicolumn{4}{|c|}{ Cafés mocas }} & \multirow{2}{*}{\multicolumn{5}{|c|}{ Cafés bons - Total (5) }} & \multirow[b]{2}{*}{ Julho } & \multirow{2}{*}{\multicolumn{2}{|c|}{ Agosto }} & \multicolumn{8}{|c|}{ Gráas de calor } & \multirow[b]{2}{*}{ Malo } & \multirow[b]{2}{*}{ Junho } & \multirow[b]{2}{*}{ TOTAIS } \\
\hline & & & & & & & & & & & & & & & & & & & & & Set. & Out. & Nov. & Dez. & Jan. & Fev. & Mar. & Abril & & & \\
\hline $1930-31$ & - & - & - & - & - & - & - & - & - & - & - & - & $\mathbf{s}$ & B & $\mathbf{N}$ & A & Ied. & 541 & 600 & & 594 & 655 & 684 & 693 & 659 & 623 & 692 & 637 & 553 & 493 & 7404 \\
\hline 1931-32 & 23 & 28 & 28 & 31 & 56 & 50 & 50 & 49 & 7 & 7 & 6 & 7 & 86 & 85 & 84 & 87 & 86 & 546 & 556 & & 564 & 641 & 640 & 716 & 690 & 707 & 713 & 670 & 572 & 489 & 7504 \\
\hline $1932-33$ & - & 6 & 12 & 14 & - & 66 & 66 & 67 & - & 5 & 6 & 6 & - & 77 & 84 & 87 & 83 & 558 & 521 & & 613 & 667 & 680 & 705 & 729 & 669 & 697 & 612 & 554 & 453 & 7458 \\
\hline $1933-34$ & 10 & 10 & 12 & 12 & 64 & 64 & 66 & 64 & 9 & 11 & 6 & 12 & 83 & 85 & 84 & 88 & 85 & 495 & 551 & & 604 & 664 & 648 & 701 & 704 & 683 & 744 & 648 & 583 & 541 & 7566 \\
\hline 1934-35 & 23 & 17 & 19 & 19 & 57 & 66 & 64 & 65 & 11 & 13 & 13 & 12 & 91 & 96 & 96 & 96 & 95 & 501 & 580 & & 592 & 670 & 716 & 731 & 739 & 653 & 737 & 593 & 512 & 530 & 7554 \\
\hline $1935-36$ & 5 & 4 & 4 & 5 & 71 & 66 & 68 & 72 & 10 & 9 & 11 & 12 & 86 & 79 & 83 & 89 & 84 & 567 & 569 & & 582 & 649 & 682 & 769 & 761 & 683 & 687 & 636 & 648 & 578 & 7811 \\
\hline $1936-37$ & 22 & 12 & 14 & 18 & 57 & 64 & 60 & 57 & 9 & 10 & 10 & 11 & 88 & 86 & 84 & 86 & 86 & 530 & 528 & & 579 & 672 & 680 & 737 & 692 & 673 & 715 & 613 & 547 & 509 & 7474 \\
\hline $1937-38$ & 8 & 4 & 6 & 5 & 60 & 63 & 68 & 66 & 14 & 20 & 16 & 29 & 82 & 87 & 90 & 90 & 87 & 543 & 587 & & 591 & 650 & e76 & 684 & $\mid 766$ & 681 & 761 & 638 & 563 & 510 & 7650 \\
\hline
\end{tabular}

(1) e (3) - Produçós relativas de cada variedade, por ano, em relaçăo ao ano de base - 1932.

(2) - Fraçסes aproximadas para ter todos as resultados em números intelros. tudo relativo ao total de café beneficiado.

(4) - Em todos as casas desta segunda parte do quadro trag
(5) - Soma das 5 primeiras peneiras e das tres de "Mocas". 


\begin{tabular}{|c|c|c|c|c|c|c|}
\hline \multirow[b]{2}{*}{$\begin{array}{l}\text { N. de } \\
\text { ordem }\end{array}$} & \multirow[b]{2}{*}{ Colheita } & \multirow[b]{2}{*}{ Tratamento } & \multicolumn{4}{|c|}{ Classificação do Instituto do Café (3) } \\
\hline & & & Tipo & Seca & Torração & Bebida \\
\hline $\begin{array}{ll}1 & \\
1 & \mathrm{~A} \\
2 & \\
2 & \mathrm{~A} \\
3 & \\
3 & \mathrm{~A} \\
4 & \\
4 & \mathrm{~A} \\
5 & \\
5 & \mathrm{~A} \\
6 & \\
6 & \mathrm{~A} \\
7 & \\
7 & \mathrm{~A} \\
8 & \\
8 & \mathrm{~A} \\
9 & \\
9 & \mathrm{~A} \\
10 & \\
10 & \mathrm{~A} \\
11 & \\
11 & \mathrm{~A}\end{array}$ & $\begin{array}{l}\text { A dedo (1) } \\
\text { Escolha do n. } 1 \text { (2) } \\
\text { Derriça } \\
\text { Escolha do n. } 2 \\
\text { A dedo } \\
\text { Escolha do n. } 3 \\
\text { A dedo } \\
\text { Escolha do n. } 4 \\
\text { Derriça } \\
\text { Escolha do n. } 5 \\
\text { A dedo } \\
\text { Escolha do n. } 6 \\
\text { A dedo } \\
\text { Escolha do n. } 7 \\
\text { Derriça } \\
\text { Escolha do n. } 8 \\
\text { A dedo } \\
\text { Escolha do n. } 9 \\
\text { A dedo } \\
\text { Escolha do n. } 10 \\
\text { Derriça } \\
\text { Escolha do n. } 11\end{array}$ & $\begin{array}{l}\text { Luz indineta, terreiro, cobertura com pano } \\
\text { Luz indireta, terreiro, cobertura com pano } \\
\text { Luz indireta, terreiro, cobertura com pano } \\
\text { Luz indireta, terreiro, cobertura com pano } \\
\text { Despolpado, terreiro, cobertura com pano } \\
\text { Despolpado, terreiro, cobertura com pano } \\
\text { Seca a sombra (4), ambiente pouco ventilado } \\
\text { Seca a sombra (4), ambilente pouco ventilado } \\
\text { Seca a sombra (4) ambte. regularmente ventilado } \\
\text { Seca à sombra (4) ambte. regularmente ventilado } \\
\text { Despolpado à sombra, ambiente muito ventilado } \\
\text { Despolpado à sombra, ambiente muito ventilado } \\
\text { Seca a pleno sol, terreiro, sol brando } \\
\text { Seca a pleno sol, terreiro, sol brando } \\
\text { Seca a pleno sol, terreiro, sol brando } \\
\text { Seca a pleno sol, terreiro, sol brando } \\
\text { Despolpado - seca a pleno sol } \\
\text { Despolpado - seca a pleno sol } \\
\text { Seca com ferment. } 42^{\circ} \mathrm{C} 2 \text { vezes - terreiro } \\
\text { Seca com ferment. } 42^{\circ} \mathrm{C} 2 \text { vezes - terreiro } \\
\text { Seca com ferment. } 42^{\circ} \mathrm{C} 2 \text { vezes - terreiro } \\
\text { Seca com ferment. } 42^{\circ} \mathrm{C} 2 \text { vezes - terreiro }\end{array}$ & $\begin{array}{l}4 \\
8 \\
3-35 \\
8 \\
3-15 \\
7 \\
3-30 \\
7-40 \\
3-10 \\
7-40 \\
3-10 \\
7-5 \\
3-45 \\
7-45 \\
4-30 \\
8 \\
4 / 5 \\
7-5 \\
4-15 \\
7-40 \\
3-45 \\
\text { Abx. }\end{array}$ & $\begin{array}{l}\text { Boa } \\
\text { Boa } \\
\text { Boa } \\
\text { Boa } \\
\text { Boa } \\
\text { Boa } \\
\text { Boa } \\
\text { Boa } \\
\text { Boa } \\
\text { Boa } \\
\text { Boa } \\
\text { Boa } \\
\text { Boa } \\
\text { Boa } \\
\text { Boa } \\
\text { Boa } \\
\text { Boa } \\
\text { Boa } \\
\text { Boa } \\
\text { Boa } \\
\text { Boa } \\
\text { Boa }\end{array}$ & \begin{tabular}{|c|} 
Boa \\
Boa \\
Reg. Boa \\
Reg. \\
Boa \\
Má \\
Boa \\
Reg. \\
Reg. \\
Má \\
Boa \\
Reg. \\
Boa \\
Má \\
Boa \\
Má \\
Boa \\
Má \\
Boa \\
Reg. \\
Boa \\
Boa
\end{tabular} & $\begin{array}{l}\text { Mole-boa } \\
\text { Mole-boa } \\
\text { Simplesmente mole } \\
\text { Dura } \\
\text { Estritamente mole } \\
\text { Simplesmente mole } \\
\text { Mole-boa } \\
\text { Mole-boa } \\
\text { Estritamente mole } \\
\text { Mole } \\
\text { Estritamente mole } \\
\text { Simplesmente mole } \\
\text { Mole } \\
\text { Simplesmente nole } \\
\text { Simplesmente mole } \\
\text { Dura } \\
\text { Estritamente mole } \\
\text { Simplesmente mole } \\
\text { Dura } \\
\text { Dura } \\
\text { Simplesmente mole } \\
\text { Dura }\end{array}$ \\
\hline
\end{tabular}

(1) - Não se trata propriamente de “colheita a dedo", senão da escolha, no terreiro, das frutos maduras, com eliminação completa de verdes e sécos. Em todos as casos tratados logo após a colheita.

(2) - Não se trata verdadeiramente de "escolhas" e sim da separação de todos os cafés que ficavam retidos pela peneira 15 (são de nos. simples), dos que lhes ficavam abaixo, para onde afluiam todos os cafés inferiores, como os mocas, quebrados, bichados, tudo emfim, menos palhas e quaisquer outros detritos (são as de nœ. seguidos da letra A. Essas "escolhas" revelavam aspeto quase ótimo nos despolpados (3A, 6A le 9A); eram ainda de aspeto muito bom nos demais.

(3) - Carta No. I-2-38-D. F. - 1481 a de 12-12-936, assinada por D. Amorim; classific. de José Largacha.

(4) - A secagem à sombra exige cuidados especiais para que se não verifique emboloramento, caso em que o café deve ir imediatamente para o sol, por algumas horas consecutivas. Foi o que fizemos varias vezes. 
slologia da planta, alnda mal conhecidos para o caso do cafeeiro. A física do solo, seu teor em matéria organica, tem que ter papel saliente. Baste-nos lembrar o retardamento da maturaçáo nos casas de adubaçరes organicas exageradas.

Das quatro variedades que vinhamos cultivando experimentalmente, tres revelaram decadencia prematura em consequencia de causas já mencionadas; o "Sumatra", todaria, por năo ter sido afetado do mesmo modo, sobreviveu em condiçбes normais de cafezal em terra velha, o qual, bem tratado yai nas proporcionar alguns elementos para a apreciaçăo daquele fenomeno biologico.

Seja ele o "Sumatra" e, melhor ainda, se for realmente - "Nacional", como preferem os técnicos do Instituto Agronomico de Campinas, as dadas que mas intimamente interessam estas observaçoes sao: a grande uniformidade do lote e o tato de ser ele constituido, desde sua origem, exclusivamente de "mudas de toco", tres por cova, em terra roxa de diabasio, velhissima de culturas anteriores.

Convém salientar que no decorrer de 20 anos de observaçరes, sôbre 244 "pés de café" deste lote (realmente 732 individuos), so constatamas duas "falhas" ou seja, menos de um por cento, 20 passo que no restante do calezal, constituldo de "Burbon", "Amarelo" e "Nacional"( Este o mesmo que - "Sumatra", segundo as opiniбes já referidas), de semeadura dineta e de mudas de jacazinho, as porcentagens de perda de plantas sempre foram multissimo mais elevadas. tesse fato vem em abono daquele tipo de muda, como fá descrevemas em outra publicaçáo (5). Mudas de mais ou menas dols anos e melo de viveiro, plantadas em 27-3-1927, já em 1931 produziram inicial frutificaçăo, que em nosso gráfico representamos abiträriamente (por năo ter sido beneficiada) por 60 quilos de café beneficlado, em consequência de năo ser inferior, na aparencia, à de 1933.

Resumimos no Quadro VIII e no gráfico correspondente os princtpais dados de produçá, desde 1931 a 1948.

Dessa expasição se conclui, o que aliás é sobejamente sabido, quão ascllante é a produção do cafeeiro no clima paulista, mesmo quando muito regularmente tratado.

(5) - "A neplanta de um deffezal" - Revista de Agricultura 1935, Viol. $10-$ N. $3-5-108$ 


\section{QUADRO VIII}

\begin{tabular}{l|c|c|c|r}
\hline Anos & Chuvas & Produção & $\begin{array}{c}\text { Números } \\
\text { proporcio- }\end{array}$ & $\begin{array}{c}\text { Números } \\
\text { proporcio- } \\
\text { nais (3) }\end{array}$ \\
& m. m. & Kgs. (1) & nais. (2) & \\
\hline $1930-31$ & 1.720 & 60 & 100 & \\
$1931-32$ & 1.213 & 817 & 1.361 & 21 \\
$1932-33$ & 1.170 & 60 & 100 & 286 \\
$1933-34$ & 953 & 387 & 645 & 21 \\
$1934-35$ & 1.230 & 100 & 166 & 135 \\
$1935-36$ & 1.292 & 468 & 780 & 35 \\
$1936-37$ & 1.411 & 402 & 670 & 164 \\
$1937-38$ & 1.037 & 484 & 806 & 141 \\
$1938-39$ & 1.577 & 60 & 100 & 170 \\
$1939-40$ & 1.356 & 255 & 425 & 21 \\
$1940-41$ & 1.064 & $70(4)$ & 116 & 89 \\
$1941-42$ & 1.392 & 398 & 663 & 24 \\
$1942-43$ & 1.289 & $0(5)$ & 0 & 140 \\
$1943-44$ & 1.371 & 578 & 963 & 203 \\
$1944-45$ & 1.605 & 71 & 118 & 24 \\
$1945-46$ & 1.119 & 303 & 505 & 106 \\
$1946-47$ & 1.307 & 346 & 576 & 99 \\
$1947-48$ & 1.391 & 283 & 471 & \\
\hline
\end{tabular}

(1) - Produção de café beneficiado tatal nos 244 fiés que consstituem experiência. A produção de 1930 não foi realmente de zero como se represtenta no gráfico; como primeira e insignificante produção, fooi desprezadia.

(2) - Números proporcionais em relação à primeira, tomada como ponto de plantida.

(3) - Números proporcionais, tomando-se como base o número 100 nepresentando a médlia de produção nos 18 anos de observação (médila de $285 \mathrm{kgs}$. ou 78 larroblas por mil pés).

(4) - Ano em que empregámos forte adubação fosfatada em todo - lote, adubação essa que sempre se maniffestou favorável até la colheita de 1948, como se deduz de outras observações.

(5) - Não foi propriamente de zero a produção de 1943 , mæıs tão mesquinha em consequência das repetidas geadas de 1942 , que assim preferimos considerar; nem ao menos realisamos sua colheita. 


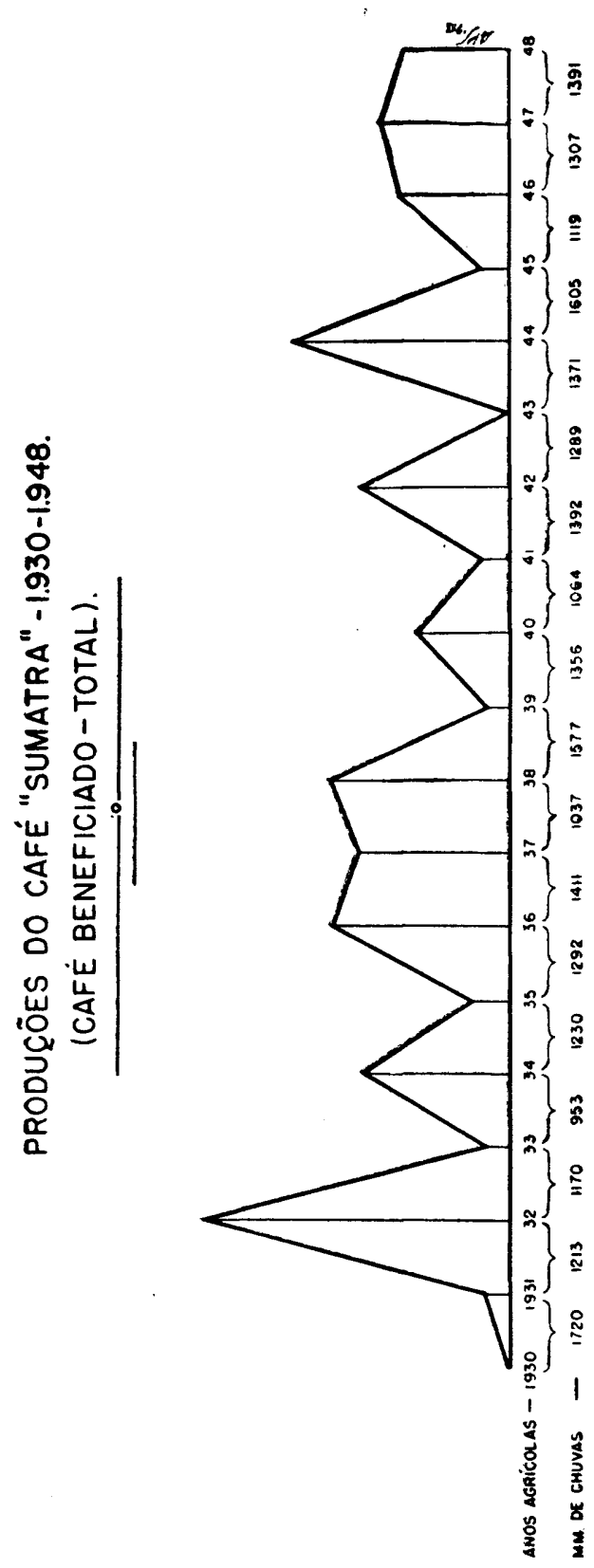




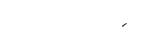

